\title{
Modelling Reef Fish Population Responses to Fisheries Restrictions in Marine Protected Areas in the Coral Triangle
}

\author{
Divya Varkey, ${ }^{1}$ Cameron H. Ainsworth, ${ }^{2}$ and Tony J. Pitcher ${ }^{1}$ \\ ${ }^{1}$ Fisheries Center, AERL, University of British Columbia, 2202 Main Mall, Vancouver, BC, Canada V6T1Z4 \\ ${ }^{2}$ College of Marine Science, University of South Florida, St. Petersburg, FL 33701, USA \\ Correspondence should be addressed to Divya Varkey, d.varkey@fisheries.ubc.ca
}

Received 14 June 2011; Revised 18 October 2011; Accepted 8 November 2011

Academic Editor: Ricardo Serrão Santos

Copyright ( 2012 Divya Varkey et al. This is an open access article distributed under the Creative Commons Attribution License, which permits unrestricted use, distribution, and reproduction in any medium, provided the original work is properly cited.

\begin{abstract}
Marine ecosystem models are used to investigate marine protected area (MPA) benefits for coral reef ecosystems located in Raja Ampat, in the heart of the Coral Triangle. Field data from an integrated and diverse research project is used to develop a spatial ecosystem model using Ecopath, Ecosim, and Ecospace modelling software. The ecological and fisheries responses of a reef ecosystem to different levels of fishing effort restrictions inside MPAs are explored. The trade-offs of allowing some fisheries to operate inside the MPAs versus designating the MPAs as no-take zones are highlighted. The results show that rapid rebuilding of reef fish populations, especially the large charismatic species, requires no-take areas. Distinct trade-offs in spillover benefits are observed between partially fished and no-take MPAs.
\end{abstract}

\section{Introduction}

A global review of the status of coral reefs found that several coral reef ecosystems have declined; the review suggests that management for status quo is a "weak" goal; rather efforts should be made to restore the reefs [1]. Marine protected areas (MPAs) have been advocated to rebuild fish populations, mediate habitat damage, and preserve ecosystem biodiversity $[2,3]$. Review of empirical results of the effects of marine reserves (i.e., no-take MPAs) shows that on average the density, biomass, diversity, and size of organisms are significantly higher inside the reserves [4]. Marine reserves appeared to promote an increased density of exploitable fishes in reef ecosystems in the Philippines $[5,6]$, the Caribbean $[7,8]$, and wherever they are adequately implemented and enforced [9]. Modelling studies have also demonstrated the biomass and spillover enhancing potential of reserves $[10,11]$. The type of response depends on the species protected [12-14], location, size, spacing of protected areas [15], growth of tourism, diving operations [16], and other factors.

Coral reefs are magnificent marine ecosystems; their incredible species richness and species composition play an important role in the ability of the ecosystems to respond to fishing and other stressors [17]. Fishing has resulted in changes to the target and nontarget reef fish communities [18-21]. Local abundances of coral reef fish are also determined by the relative magnitudes of larvae recruitment, colonization by juveniles and adults, predation, and competition for refuges [22]. Similar to the changes observed with fishing, recovery is also dependent on the competitive balance and trophic composition of reef ecosystems [23, 24]. A spatial ecosystem model of the coral reef ecosystem can offer insights into the complexity of relationships and suggest options for management of MPAs. An important question in designing MPAs for reef ecosystems is what level of fishing restriction inside MPAs is necessary to obtain increased size and abundance of reef fish species - could some fisheries be allowed or should MPAs be designated as no-take zones? And, are the responses similar for all reef fish species? The objectives of this study are to explore different types of fishing restrictions inside an MPA and the implications for (i) resulting rebuilding effect on the fish populations inside the MPA under full restriction or partial restrictions on commercial and destructive fisheries, (ii) fisheries within the spillover region and fisheries within the MPA under partial 
fishing closures, and (iii) the effect of adjacent (spillover) fisheries on population dynamics within the MPA.

\section{Methods}

2.1. Study Area. Raja Ampat, in Eastern Indonesia, is located in the heart of the Coral Triangle (Figure 1). The area encompasses a variety of marine habitats including some of the most biodiverse coral reef areas in the world $[25,26]$. It is estimated that Raja Ampat possesses over 75\% of the world's known coral species [27]. The coral reef ecosystem is still relatively intact. A survey across 45 reef sites in 2002 in Raja Ampat revealed that 50\% of reef sites were in "excellent" to "good" condition measured in terms of fish diversity, coral diversity, and coral cover, although some form of stress or damage was observed on $85 \%$ of the surveyed sites [28]. The predominant stressors were fishing pressure (including destructive fishing methods), siltation, and eutrophication/pollution. A decree by the Bupati (Regent) in 2003 declared Raja Ampat a maritime regency "Kabupaten Bahari" [29]; the regency adopted the goal of improving the welfare and prosperity of human communities by promoting fisheries, conservation, and tourism [30]. Studies of fisher perceptions in Raja Ampat showed that the fishers believed that fish catch had declined over the past 10 to 20 years $[31,32]$. Concerned with the issues of fisheries management and with the intention to develop environmentally sound ecosystem-based policies, the government in 2006 set up a network of seven MPAs encompassing 44\% of the reef area. The Regency government also participated in a collaborative project-the Birds Head Seascape EcosystemBased Management (BHS EBM) project-involving three environmental NGO partners-Conservation International (CI), The Nature Conservancy (TNC), and World Wide Fund (WWF) - in a science-based initiative in partnership with local stakeholders and academic partners to explore ecosystem processes relevant to management. Raja Ampat ecosystem models were developed as part of this project using the Ecopath with Ecosim (EwE) modelling framework [33-35]. With respect to marine protected areas, the research questions explored were identified through discussions with the Regency fisheries managers and scientific partners working in Eastern Indonesia. Ecological responses in three of the seven MPAs (Kofiau $328 \mathrm{~km}^{2}$; Southeast Misool $943 \mathrm{~km}^{2}$; Dampier Strait $202 \mathrm{~km}^{2}$ ) are investigated in this paper. Kofiau is a small island with only a few fishing villages (Figure 1), Misool is more densely populated island, is closer to the industrial city of Seram, and has more fishing villages. Dampier Strait is located between mainland Papua and the Waigeo Island of Raja Ampat. Fishers from the Waigeo and Batanta Islands of Raja Ampat and from Sorong, capital city of Papua, fish in the Dampier Strait.

\subsection{Ecopath with Ecosim and Ecospace Model of Raja Ampat.} The EwE modelling approach is used to build a coral reef ecosystem model [33-35], and Ecospace is used for spatial analysis of MPAs. EwE is a mass balance trophic simulation model that acts as a thermodynamic accounting system for marine ecosystems. Ecopath is a static snapshot of the system [36] that maps the interspecies interactions through predator-prey linkages. Ecosim is dynamic and allows modelling of species composition changes over time [37, 38]. Ecospace integrates Ecopath and Ecosim across a two dimensional spatially explicit domain [39, 40]. Following is a brief description of the underlying Raja Ampat Ecopath and Ecosim model which was used for the Ecospace model presented here; an extended summary of data sources is provided in Appendix A and more detail on data and model development is documented in technical reports [34, 35]. Functional groups in EwE models are either species or species groups that can be aggregated based on feeding guild, habitat, body size, or other niche determinants. The Raja Ampat EwE model has 98 functional groups - 57 fish groups representing 1203 fish species, 22 groups of invertebrates, 9 groups of mammals, turtles, or birds, 4 groups of jellyfish or zooplankton, 4 groups of primary producers, and 2 detritus groups (Table 2). With a limited number of functional groups, we are forced to limit our representation of noncommercial species (e.g., cryptobenthic species which function predominantly as detritivores and small carnivores in the reef ecosystem [41]). However, cryptic species are aggregated into functional groups (e.g., small demersal fish and small reef fish), and these functional groups would tend to partly reflect the cryptic behaviour through vulnerability parameters in Ecosim. Commercial importance of species and their functional roles were considered in designing the functional groups in the model-the groups were first established based on literature $[17,25]$ and then revised at a "model coordination workshop" with local scientists and field staff held in 2007 in Sorong, Indonesia. The predatorprey interactions between species were described by diet linkages. Stomach content analysis on fish purchased from the markets in Sorong was used to inform the diet interactions (source: Christovel Rotinsulu, Conservation International, JL Gunung Arfak. No 45. Sorong, Papua, Indonesia. Email: chris@conservation.or.id).For noncommercial species, a diet algorithm was designed based on the FishBase diet table [42] and the size of the fish in the functional group. For invertebrate species, diet information was obtained from a literature review. Reef monitoring SCUBA and snorkeling diving transects on reef sites selected using a stratified random approach were used to inform the biomass estimates for several functional groups and coral coverage in the model. Biomass for other functional groups was obtained from previous reef surveys in Raja Ampat [43], estimates from literature, and in some cases the EwE model was allowed to estimate the biomass conditioned on other constraints of diets and predation mortality.

The fishing gear types included in the model were selected based on discussions with local fisheries experts and on Indonesian fishery records and publications [44]. The fisheries catch statistics were assembled from the Sorong Regency Fisheries Office (Departemen Kelautan dan Perikanan, DKP), the Raja Ampat Regency Fisheries Office, and the Trade and Industry Office (Departemen Perinustrian dan Perdagangan). Additionally, TNC field teams conducted aerial surveys of fishing effort in Raja Ampat in 2006. Resource use surveys on fishing gear, and vessels were conducted 

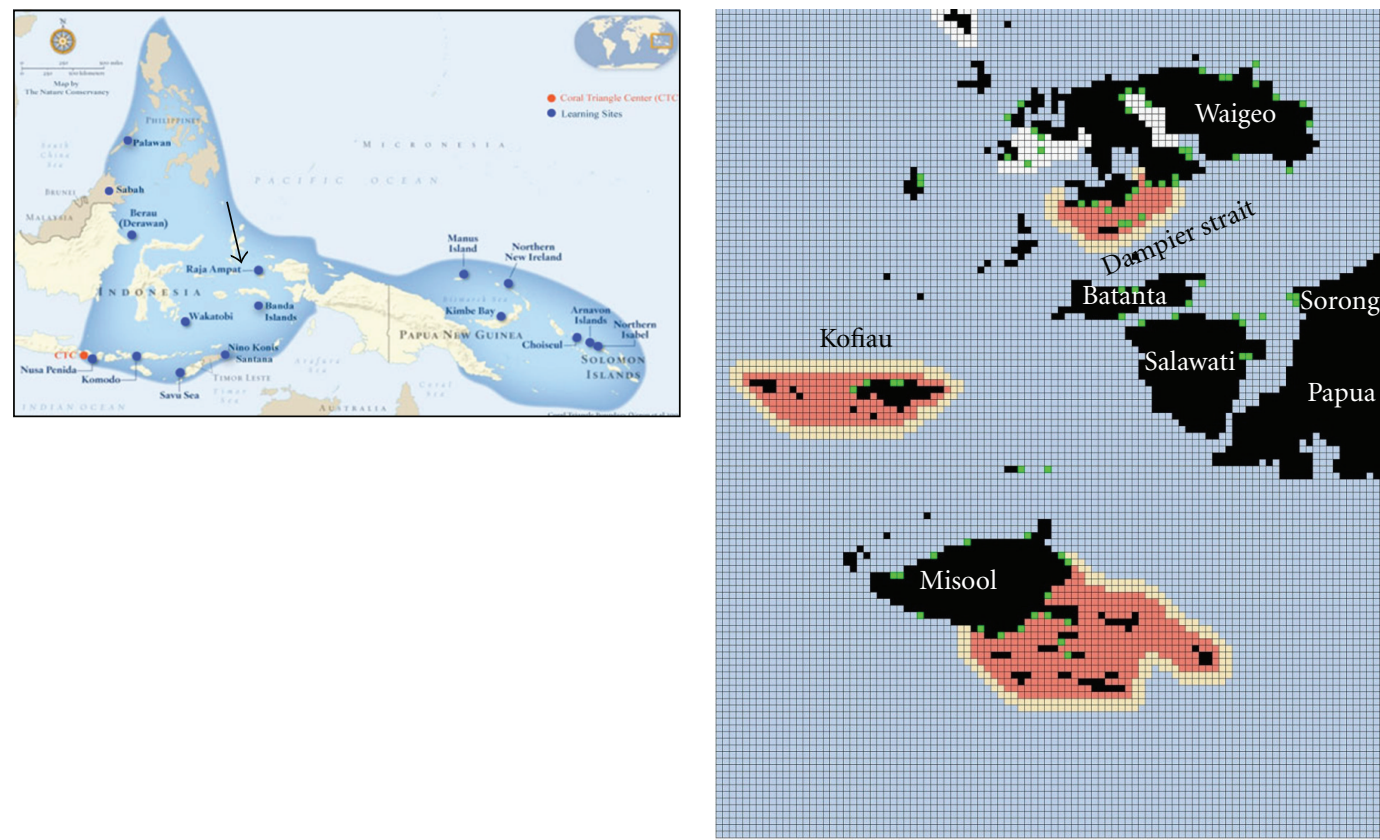

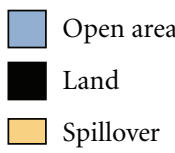

(a)

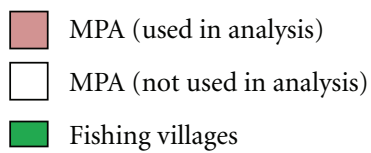

(b)

Figure 1: (a) Location of Raja Ampat in the coral triangle (source: The Nature Conservancy Coral Triangle Center http://www.coraltrianglecenter.org/en/page/coral-triangle). The blue shaded region shows the boundary of the coral triangle and the arrow points to the location of Raja Ampat; (b) MPA boundaries. The figure shows the names and boundaries of the three MPAs on which the study is based (pink), spillover regions (yellow), fishing villages (green), and MPAs not part of the analysis (white). Each cell in the map is approximately $2.56 \mathrm{x}$ $2.57 \mathrm{~km}$. The city of Seram mentioned in the text is located on mainland Papua towards east of Misool.

on Kofiau Island of Raja Ampat by a mobile monitoring team from TNC (source: Andreas Muljadi (The Nature Conservancy Coral Triangle Center. JL Gunung Arfak. No 38, Kampung Baru. Sorong, Papua, Indonesia. Email: amuljadi@tnc.org). Information on fishers and the species they targeted was available from a coastal rural appraisal on Kofiau and Misool [31]. Information on shark fishing was available from fishing villages in Waigeo [45]. These different sources of information were combined to estimate the unreported catch in Raja Ampat [46], and these estimates were added to the reported fisheries catch. The data were collated into catch and effort time series and converted into standard units for use in Ecosim. Two models were built to represent the past (1990) and present (2005) ecosystems and the models vulnerability parameters in the 1990 model were tuned during the process of fitting the model to observed time series data from 1990 to 2005. The 2005 EwE model was initialised by transferring the trophic vulnerabilities from the 1990 model under the assumption of stationarity in foraging behaviour from 1990 to 2005 (see [34]). Trophic vulnerabilities are critical dynamic parameters used by Ecosim to define density-dependent predator-prey functional relationships. These parameters regulate the trade-off between hiding (low predation mortality, low growth rate) and foraging (high
TABLE 1: Analysis of variance of biomass change in MPAs against dispersal rates, trophic level, and adult versus juvenile life stages.

\begin{tabular}{lcccccc}
\hline & Df & Sum Sq & Mean Sq & $F$ value & $\operatorname{Pr}(>F)$ & \\
\hline Dispersal rate & 4 & 9.40 & 2.35 & 6.26 & 0.0001 & $* * *$ \\
Trophic level & 3 & 2.47 & 0.82 & 2.19 & 0.0914 &. \\
Adult-Juv & 1 & 3.07 & 3.07 & 8.17 & 0.0048 & $* *$ \\
Residuals & 159 & 59.68 & 0.38 & & & \\
\hline Signif. codes: 0 “***”, 0.001 “**”, 0.01 “*”, 0.05 “., 0.1 “” 1. &
\end{tabular}

predation mortality, high predation mortality) behaviours. The 2005 EwE model was used for fisheries policy analysis: a synthesis of the model specifications and predictions is published in Ainsworth et al. [33].

The Ecospace model presented in this paper is the spatial extension of the 2005 EwE model of Raja Ampat-also referred to as the base model and is built in order to explore spatial research questions related to MPAs for coral reef ecosystems. Previous authors have used Ecospace to explore spatial questions [10, 39, 47-49]. In Ecospace, the study area is represented using a grid of habitat types. Each functional group is allocated to its appropriate habitat(s). Each cell in 
TABLE 2: Functional groups, habitat specifications, and dispersal rates in Raja Ampat Ecospace model.

\begin{tabular}{|c|c|c|c|c|c|c|c|c|}
\hline Functional groups & Reef & $\begin{array}{c}10 \mathrm{~m} \\
\text { Isobath }\end{array}$ & $\begin{array}{c}20 \mathrm{~m} \\
\text { Isobath }\end{array}$ & $\begin{array}{l}200 \mathrm{~m} \\
\text { Isobath }\end{array}$ & $\begin{array}{c}\text { Deep } \\
>200 \mathrm{~m}\end{array}$ & $\mathrm{TL}$ & $\begin{array}{c}\text { Dispersal } \\
\text { rate } \\
\mathrm{km} \cdot \mathrm{yr}^{-1}\end{array}$ & $\begin{array}{c}\text { Dispersal rate } \\
\text { reference }\end{array}$ \\
\hline Mysticetae & & & & + & + & 3.49 & 10000 & {$[92]$} \\
\hline Piscivorous odontocetae & & & + & + & + & 4.22 & 1000 & [93] \\
\hline Deepdiving odontocetae & & & & + & + & 4.05 & 10000 & {$[94]$} \\
\hline Dugongs & & + & + & & & 2.00 & 300 & (default) \\
\hline Birds & + & + & + & + & + & 3.59 & 300 & (default) \\
\hline Reef associated turtles & + & + & + & & & 3.27 & 1000 & {$[95]$} \\
\hline Green turtles & & + & + & + & + & 2.20 & 1000 & {$[96,97]$} \\
\hline Oceanic turtles & & + & + & + & + & 3.44 & 10000 & {$[98]$} \\
\hline Crocodiles & & + & + & & & 3.98 & 300 & (default) \\
\hline Adult groupers & + & & & & & 3.65 & 30 & {$[56]$} \\
\hline Subadult groupers & + & & & & & 3.70 & 220 & {$[99,100]$} \\
\hline Juvenile groupers & + & & & & & 3.70 & 100 & {$[59]$} \\
\hline Adult snappers & + & & & & & 3.72 & 30 & {$[56]$} \\
\hline Subadult snappers & + & & & & & 3.66 & 350 & {$[99,100]$} \\
\hline Juvenile snappers & + & & & & & 3.85 & 150 & {$[59]$} \\
\hline Adult Napoleon wrasse & + & & & & & 3.85 & 30 & {$[56]$} \\
\hline Subadult Napoleon wrasse & + & & & & & 3.62 & 100 & (guess) \\
\hline Juvenile Napoleon wrasse & + & & & & & 3.40 & 150 & {$[59,101]$} \\
\hline Skipjack tuna & & + & + & + & + & 4.09 & 1000 & {$[102]$} \\
\hline Other tuna & & + & + & + & + & 4.05 & 1000 & {$[103]$} \\
\hline Mackerel & & + & + & + & & 3.79 & 1000 & {$[104]$} \\
\hline Billfish & & & & + & + & 4.44 & 1000 & {$[105]$} \\
\hline Adult coral trout & + & & & & & 3.88 & 6 & {$[55]$} \\
\hline Juvenile coral trout & + & & & & & 3.85 & 150 & {$[59]$} \\
\hline Adult large sharks & & & & + & + & 4.15 & 300 & (guess) \\
\hline Juvenile large sharks & & & + & + & + & 3.86 & 300 & (guess) \\
\hline Adult small sharks & & & + & + & & 4.28 & 100 & (guess) \\
\hline Juvenile small sharks & & & + & + & & 4.11 & 100 & (guess) \\
\hline Whale shark & + & + & + & + & + & 3.82 & 1000 & {$[106]$} \\
\hline Manta ray & + & + & + & + & + & 3.74 & 1000 & (guess) \\
\hline Adult rays & + & + & + & + & & 3.31 & 1000 & (guess) \\
\hline Juvenile rays & + & + & + & + & & 3.42 & 1000 & (guess) \\
\hline Adult butterflyfish & + & + & & & & 2.97 & 5 & {$[54]$} \\
\hline Juvenile butterflyfish & + & & & & & 2.77 & 10 & {$[107]$} \\
\hline Cleaner wrasse & + & & & & & 3.30 & 3 & (guess) \\
\hline Adult large pelagic & & + & + & + & + & 3.89 & 500 & {$[108]$} \\
\hline Juvenile large pelagic & & + & + & + & & 3.64 & 500 & {$[108]$} \\
\hline Adult medium pelagic & & + & + & + & + & 3.62 & 300 & (guess) \\
\hline Juvenile medium pelagic & & + & + & + & & 3.45 & 300 & (guess) \\
\hline Adult small pelagic & + & + & + & + & & 3.59 & 200 & (guess) \\
\hline Juvenile small pelagic & + & + & + & + & & 2.63 & 200 & (guess) \\
\hline Adult large reef associated & + & & & & & 2.95 & 50 & {$[54,56,57]$} \\
\hline Juvenile large reef associated & + & & & & & 3.06 & 150 & {$[59]$} \\
\hline Adult medium reef & + & & & & & 3.08 & 50 & {$[54,56,57]$} \\
\hline Juvenile medium reef & + & & & & & 2.38 & 150 & [59] \\
\hline
\end{tabular}


TABle 2: Continued.

\begin{tabular}{|c|c|c|c|c|c|c|c|c|}
\hline Functional groups & Reef & $\begin{array}{l}10 \mathrm{~m} \\
\text { Isobath }\end{array}$ & $\begin{array}{l}20 \mathrm{~m} \\
\text { Isobath }\end{array}$ & $\begin{array}{l}200 \mathrm{~m} \\
\text { Isobath }\end{array}$ & $\begin{array}{c}\text { Deep } \\
>200 \mathrm{~m}\end{array}$ & $\mathrm{TL}$ & $\begin{array}{l}\text { Dispersal } \\
\text { rate } \\
\mathrm{km} \cdot \mathrm{yr}^{-1}\end{array}$ & $\begin{array}{l}\text { Dispersal rate } \\
\text { reference }\end{array}$ \\
\hline Adult small reef associated & + & & & & & 2.76 & 30 & {$[54,57]$} \\
\hline Juvenile small reef associated & + & & & & & 2.70 & 100 & [59] \\
\hline Adult large demersal & & + & + & + & + & 3.21 & 200 & (guess) \\
\hline Juvenile large demersal & & + & + & + & & 3.47 & 200 & (guess) \\
\hline Adult small demersal & & + & + & + & & 3.61 & 100 & (guess) \\
\hline Juvenile small demersal & & + & + & + & & 3.22 & 100 & (guess) \\
\hline Adult large planktivore & + & & + & + & + & 3.39 & 200 & (guess) \\
\hline Juvenile large planktivore & + & + & + & + & & 3.48 & 1000 & {$[108]$} \\
\hline Adult small planktivore & + & + & + & & & 3.23 & 200 & (guess) \\
\hline Juvenile small planktivore & + & + & + & & & 2.52 & 1000 & {$[108]$} \\
\hline Adult anchovy & + & + & + & & & 3.31 & 500 & (guess) \\
\hline Juvenile anchovy & + & + & + & & & 2.14 & 500 & (guess) \\
\hline Adult deepwater fish & & & & & + & 3.83 & 300 & (default) \\
\hline Juvenile deepwater fish & & & & + & + & 3.37 & 300 & (default) \\
\hline Adult macro algal browsing & + & & & & & 2.47 & 50 & {$[54]$} \\
\hline Juvenile macro algal & + & & & & & 2.16 & 100 & {$[59]$} \\
\hline Adult eroding grazers & + & & & & & 2.45 & 50 & {$[54]$} \\
\hline Juvenile eroding grazers & + & & & & & 2.71 & 100 & {$[59]$} \\
\hline Adult scraping grazers & + & & & & & 2.16 & 5 & {$[54]$} \\
\hline Juvenile scraping grazers & + & + & & & & 2.33 & 100 & [59] \\
\hline Detritivore fish & + & + & + & + & & 2.24 & 50 & (guess) \\
\hline Azooxanthellate corals & + & + & & & & 2.50 & 2 & {$[52]$} \\
\hline Hermatypic scleractinian & + & & & & & 1.30 & 1 & {$[52]$} \\
\hline Non reef building & + & & & & & 1.30 & 2 & {$[52]$} \\
\hline Soft corals & + & + & & & & 1.75 & 2 & {$[52]$} \\
\hline Calcareous algae & + & & & & & 1.00 & 2 & {$[51]$} \\
\hline Anemones & & + & & & & 3.15 & 5 & (guess) \\
\hline Penaeid shrimps & & + & + & + & + & 2.51 & 100 & {$[109]$} \\
\hline Shrimps and prawns & + & + & + & & & 2.02 & 30 & {$[110]$} \\
\hline Squid & & & & + & + & 3.49 & 300 & (default) \\
\hline Octopus & + & + & + & & & 3.40 & 50 & {$[111]$} \\
\hline Sea cucumbers & + & + & + & & & 2.00 & 20 & {$[51]$} \\
\hline Lobsters & + & + & + & + & & 3.23 & 20 & {$[51]$} \\
\hline Large crabs & + & + & + & + & & 2.95 & 20 & {$[51]$} \\
\hline Small crabs & + & + & + & & & 2.51 & 20 & {$[51]$} \\
\hline Crown of thorns & + & & & & & 2.47 & 20 & {$[51]$} \\
\hline Giant triton & + & & & & & 3.34 & 20 & {$[51]$} \\
\hline Herbivorous echinoids & + & + & + & & & 2.00 & 20 & {$[51]$} \\
\hline Bivalves & + & + & + & + & & 2.20 & 20 & {$[51]$} \\
\hline Sessile filter feeders & + & + & + & + & & 2.32 & 20 & {$[51]$} \\
\hline Epifaunal detritivorous & + & + & + & & & 2.00 & 20 & {$[51]$} \\
\hline Epifaunal carnivorous & + & + & + & & & 2.92 & 20 & {$[51]$} \\
\hline Infaunal invertebrates & & + & + & + & & 2.01 & 20 & {$[51]$} \\
\hline Jellyfish and hydroids & + & + & + & + & + & 3.10 & 300 & (default) \\
\hline Carnivorous zooplankton & + & + & + & + & + & 3.18 & 300 & (default) \\
\hline
\end{tabular}


TABLE 2: Continued.

\begin{tabular}{|c|c|c|c|c|c|c|c|c|}
\hline Functional groups & Reef & $\begin{array}{c}10 \mathrm{~m} \\
\text { Isobath }\end{array}$ & $\begin{array}{c}20 \mathrm{~m} \\
\text { Isobath }\end{array}$ & $\begin{array}{c}200 \mathrm{~m} \\
\text { Isobath }\end{array}$ & $\begin{array}{c}\text { Deep } \\
>200 \mathrm{~m}\end{array}$ & $\mathrm{TL}$ & $\begin{array}{l}\text { Dispersal } \\
\text { rate } \\
\mathrm{km} \cdot \mathrm{yr}^{-1}\end{array}$ & $\begin{array}{l}\text { Dispersal rate } \\
\text { reference }\end{array}$ \\
\hline Large herbivorous & + & + & + & + & + & 2.00 & 300 & (default) \\
\hline Small herbivorous & + & + & + & + & + & 2.00 & 300 & (default) \\
\hline Phytoplankton & + & + & + & + & + & 1.00 & 300 & (default) \\
\hline Macro algae & + & + & + & & & 1.00 & 20 & {$[51]$} \\
\hline Sea grass & & + & + & & & 1.00 & 6 & {$[51]$} \\
\hline Mangroves & & + & & & & 1.00 & 5 & (guess) \\
\hline Fishery discards & + & + & + & + & + & 1.00 & 10 & (default) \\
\hline Detritus & + & + & + & + & + & 1.00 & 10 & (default) \\
\hline
\end{tabular}

the habitat grid hosts its own Ecosim simulation and is linked through symmetrical biomass flux in four directions. The two essential components of an Ecospace model are therefore the habitat map of the region and the parameters that govern dispersal rates of the species across the habitat map.

2.3. Habitat Map. The habitat map is based on GIS information assembled by the Birds Head Seascape Ecosystem-Based Management (BHS EBM) project as well as oceanographic and biological data from the literature. The Raja Ampat Ecospace map is $100 \times 120$ cells and describes an area about $256 \mathrm{~km}$ east to west and $321 \mathrm{~km}$ north to south; each cell represents an area of $2.56 \times 2.57 \mathrm{~km}$, or approximately $6.57 \mathrm{~km}^{2}$, at midlatitudes. The north-westernmost coordinate lies at $129^{\circ} 12^{\prime} \mathrm{E}, 0^{\circ} 12^{\prime} \mathrm{N}$, and the south-easternmost coordinate lies at $130^{\circ} 30^{\prime} \mathrm{E}, 2^{\circ} 42^{\prime} \mathrm{S}$. Five aquatic habitat types are used in the Raja Ampat Ecospace model (Figure 2). The habitats are based on bathymetry, with 10, 20, 200, and $>200 \mathrm{~m}$ isobaths and reef distribution. There were two constraints as to why a higher habitat resolution could not be used in the analysis: (i) since each cell in the habitat map covered about $6.57 \mathrm{~km}^{2}$, partitioning between different reef types would require a finer resolution of habitat cells, (ii) many of the functional groups included in the model are aggregate groups containing many species (e.g., "small reef fish"), and at this coarse level of grouping it was difficult to apportion the different functional groups to different types of reefs. Bathymetric information was obtained from Indonesian nautical charts collected by the BHS-EBM project in GIS files (contact: M. Barmawi, TNC-CTC. Jl Pengembak 2, Sanur, Bali, Indonesia). Habitat areas for reefs are based on more recent BHS EBM project GIS outputs [50].The GIS shapefiles were converted to ASCII formats which could be incorporated into Ecospace. Simple heuristic rules were used to assign the functional groups to their preferred habitats. Reef species were associated with reef habitats, large pelagic species like tuna were associated with broad depth ranges, and small planktivorous species were associated with reefs and continental shelf waters (Table 2). The exchange rate of biomass between the cells is determined mainly by dispersal rates in combination with the habitat type in adjacent cells, and group foraging and predator avoidance behaviour [39]. Availability of optimal or suboptimal habitat in adjacent cells and dispersal rate parameters of the functional groups determine the dispersal of the functional group into adjacent cells. Optimality depends on the density of prey and predators-prey availability and predation pressure in the cell are both ascertained based on parameters inherited from the Ecopath and Ecosim models.

2.4. Dispersal Rates. Dispersal rates represent net residual movement of functional groups on an annual basis and are not related to swimming speeds (see Walters et al. [39] for more details). For reef fish, the dispersal rate is most heavily influenced by the motility and duration of the larval phase, advection rates for propagules as related to local hydrodynamics, and by the degree of natal-area fidelity in breeding populations. The dispersal rates also reflect the degree to which random movements and exploratory behaviour lead to colonization. The dispersal rate parameters in Ecospace are used to calculate the fraction of biomass of the functional group in the cell that would move into the adjacent cell at the next time step (adjusted by the availability of optimal and suboptimal habitats) and hence are important in generating the spatial distribution of organisms in the ecosystem. The higher the density gradient between two cells, the greater is the movement from one cell to the other. The dispersal rates (Table 2) were adjusted according to the movement patterns of functional groups based on published literature and expert comments made by Dr Neil Gribble (contact: Queensland Dept of Primary Industries \& Fisheries, Northern Fisheries Center, Cairns. Email: Neil.gribble@dpi.qld.gov.au). The following is a brief description of dispersal rates used for corals and reefassociated fish in the model.

Dispersal rates for coral species range from $1-3 \mathrm{~km} \cdot \mathrm{yr}^{-1}$ based on observations that coral reefs primarily self-seeded with highest settlement density at $500 \mathrm{~m}$ distance from the adult population [51]. The value also considers the conclusions of Sammarco and Andrews [52] that coral recruitment declined logarithmically with distance from the reef. However calculations based on stored energy and settlement time have shown that coral larvae are capable of longdistance dispersal [53]. The dispersal rates for adult reef fish range from 5 to $50 \mathrm{~km} \cdot \mathrm{yr}^{-1}$. Studies have concluded that butterfly fish "spent their entire lives associated with a small 


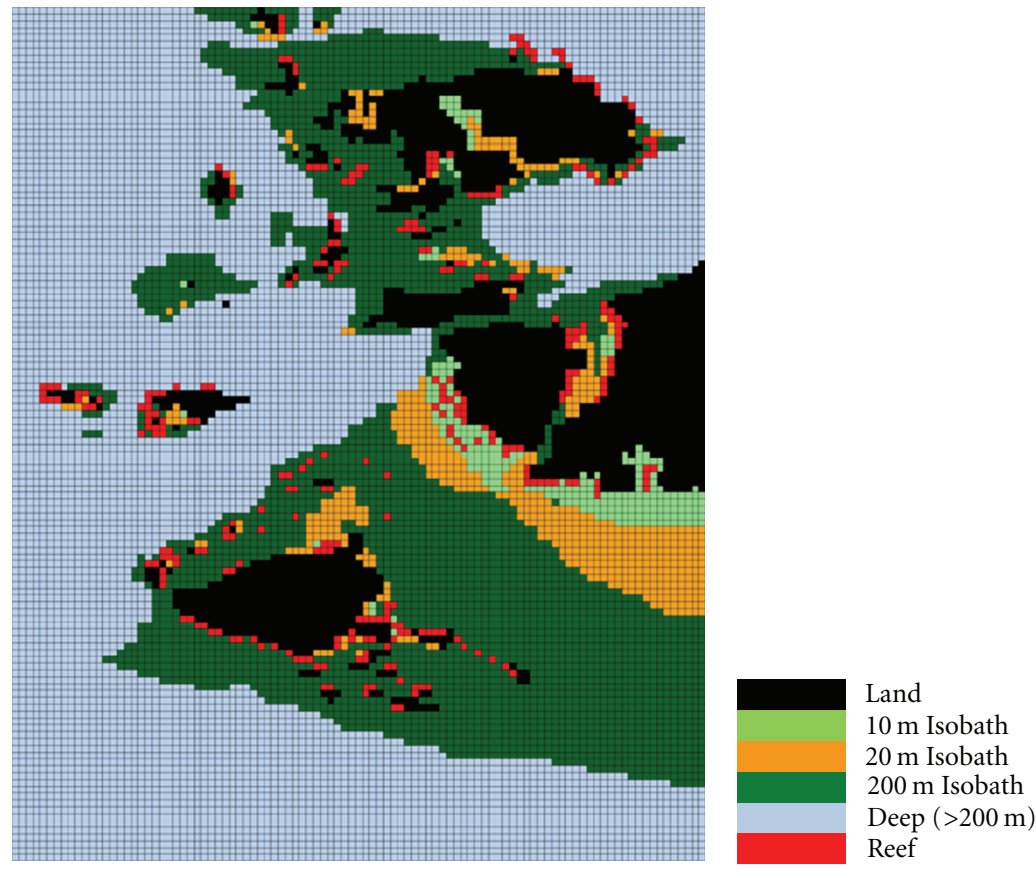

FIgURE 2: Raja Ampat Ecospace habitat map. Each cell in the map is approximately $2.56 \times 2.57 \mathrm{~km}$.

portion of the reef" [54]. Similar results were observed for angelfish and surgeon fish $[54,55]$. Groupers range within $20 \mathrm{~km}$ [54]; Lutjanidae range within $20 \mathrm{~km} \mathrm{[56].} \mathrm{However,}$ several other studies have indicated higher dispersion ranges $[55,57,58]$ but the values chosen (grouper $30 \mathrm{~km} \cdot \mathrm{yr}^{-1}$, snapper $30 \mathrm{~km} \cdot \mathrm{yr}^{-1}$ ) were based on expert consultation with Dr Neil Gribble. Other groups of adult reef fish in the model were assigned dispersal rates of $50 \mathrm{~km} \cdot \mathrm{yr}^{-1}$ based on studies that concluded that fishes of families Siganidae, Caesionidae, and Pomacentridae are highly mobile [56, 57], though other families like Haemulidae do not disperse long distances [54]. Dispersal rates for juvenile reef fish range from 100 to $150 \mathrm{~km} \cdot \mathrm{yr}^{-1}$ [59]. Other studies suggest that fish larvae are retained "at natal reefs", in a range of $30 \mathrm{~km}[55,60]$; however, maximum suggested distance of larval transport from one reef to another is $219 \mathrm{~km}$ [61]. The lengthy spawning migrations were not considered because the dispersal rate in Ecospace does not represent directed migration pattern. The high dispersal rates chosen for juvenile reef fish functional groups essentially capture the dispersal behaviour of larvae and juveniles.

2.5. Spatial Distribution of Fishing Effort. Ecospace estimates the amount of fishing effort occurring in a map cell by assuming an ideal free distribution (IFD) of fishing effort. Under this assumption, profitable areas, such as areas possessing high resource abundance or near shore areas with low sailing costs, are targeted by a larger number of fishers than less profitable areas [62]. When establishment of an MPA causes export of fish into the adjacent areas, these areas would receive higher fishing efforts owing to the improved profitability of these zones; higher fishing effort has been empirically observed on reserve boundaries
$[63,64]$. Recognising that fishing effort dynamics is important to consider when evaluating MPAs and spillover regions [64], the locations of the fishing villages were provided as inputs in the Ecospace map (Figure 1) and were used to calculate the fishing cost. The locations were obtained from the administrative map of Raja Ampat [50].

2.6. Ecosystem Effects of Fisheries Restrictions inside the MPAs. The following paragraphs describe the three types of fishing restrictions employed in the Raja Ampat MPAs (Figure 1) in the Ecospace model. The fisheries in Raja Ampat include spear fishing, reef gleaning, shore gillnets, driftnets, permanent and portable traps, spear diving, diving for live fish, cyanide fishing, blast fishing, trolling, purse seining, pole and line, hook and line, lift nets, and shrimp trawls. The following fisheries were assumed to be commercial: driftnet, diving for live fish, diving with cyanide, blast fishing, trolling, purse seine, and pole and line. The other gear types were assumed to be primarily artisanal: spear and harpoon, reef gleaning, shore gillnets, permanent trap, portable trap, diving with spear, and set line. The distinction between artisanal and commercial catch is difficult to draw due to the unreported and unregulated nature of Raja Ampat reef fish fisheries and widespread casual local trade. The gear types were chosen to highlight the distinction between fishing sectors that require low capital investment and/or whose products are destined for a small-scale local market versus fishing sectors that require high capital investment and/or whose products are destined for regional or international market. Capital-intensive fishing methods such as compressor diving and fisheries that produce a high value product suitable for export, such as cyanide fishing, were assumed to be commercial. Blast fishing and cyanide fishing represent 
destructive fishing methods in Raja Ampat. The following three levels of fishing restrictions were imposed in the MPAs: (i) No-take zone (no fishing allowed), (ii) commercial fisheries restricted (artisanal fisheries allowed), and (iii) destructive (blast fishing and cyanide) fisheries restricted. At the end of 20-year simulations, ecosystem recovery was examined through changes in biomass density and catch density of reef fish inside the MPAs and catch density in the spillover regions (two-cell wide region adjacent to the MPAs (Figure 1)).

\section{Results}

3.1. Reef Fish Biomass Density inside MPA. For the purpose of summarizing the results, the reef fish species in the Raja Ampat Ecospace model were aggregated into 3 categories: large reef fish, medium reef fish, and small reef fish. Status quo scenario refers to the situation when fishing was not restricted in the MPAs, and fishing mortality in the 20-year simulation period remained constant at the baseline fishing mortality in the 2005 EwE model initialization. Under status quo the biomass density of large and medium fish decreased relative to baseline biomass density (2005 EwE model) in all the MPAs. This indicates that current levels of fishing will lead to further declines in the biomass density of large and medium reef fish species. In Misool and in Dampier Strait, the small reef fish were observed to increase under status quo scenario.

When destructive fishing alone was restricted, reef fish benefited relative to the status quo scenario, but the restriction was not sufficient to ensure rebuilding of the large and medium reef fish from their baseline biomass density levels (Figure 3). Under restriction of all commercial fisheries, a modest rebuilding of large reef fish population was observed in all MPAs (Kofiau 15\%, Misool 8\%, and Dampier Strait 28\%). A definite increase in biomass density of large reef fish was observed only when all fishing was restricted (Kofiau 67\% increase, Misool 92\%, and Dampier Strait 112\%) (Figure 3).

A trophic cascade was evident in all the MPAs. In response to increased biomass density of large reef fish, the biomass density of medium reef fish decreased, thereby releasing the small reef fish from predation. Medium reef fish increased above their base levels only in the Dampier Strait MPA in the "no fishing" scenario. Compared to the "status quo" scenario, the decline in medium reef fish was lower under fishing restriction scenarios, but the benefits of the MPAs were dampened by increased predation pressure from large reef fish. In Misool and in Dampier Strait MPAs, the highest increase in small reef fish $(\sim 140 \%)$ occurred when all commercial fishing was restricted. When all fishing was closed, the increased predation pressure caused a decrease in the biomass density of small reef fish in Dampier Strait and Misool.

Ecospace model results were sensitive to dispersal rates (Figure 4). The change in biomass density of fish functional groups under complete fishing restriction in the MPA was analysed using an ANOVA. For the ANOVA, dispersal rates were grouped into five categories $\left(<30 \mathrm{kmyr}^{-1}\right.$,
30-50 $\mathrm{kmyr}^{-1}, 50-100 \mathrm{kmyr}^{-1}, 100-200 \mathrm{kmyr}^{-1}$, and >300 $\mathrm{kmyr}^{-1}$ ), trophic level of the species was grouped into four categories $(2-2.5,2.5-3,3-3.5$, and $>3.5)$, and a distinction between adults and juveniles was made. The results of the ANOVA (Table 1) showed that effects of dispersal rate and adult-juvenile distinction were significant, and the trophic level effect was significant at $\alpha=0.1$. Prominent rebuilding effects were seen in species with low dispersal rates $\left(<30 \mathrm{~km} \cdot \mathrm{yr}^{-1}\right)$, especially in the lower trophic level functional groups. The rebuilding effect was also related to the adult or juvenile life stage-in general juveniles showed lower rebuilding levels in comparison to adults.

3.2. Reef Fish Catch inside MPA and inside Spillover Regions. Under status quo, biomass density and catch of large reef fish (Misool 49\%, Dampier Strait 24\%) and medium reef fish (Misool 41\%, Dampier Strait 43\%) decreased from the baseline (EwE 2005) levels. The decrease in predator biomass density caused a subsequent increase in biomass density and catch of small reef fish in Misool and in Dampier Strait MPAs (Figure 5). Small reef fish yield increased in Misool and in Dampier Strait MPAs. The response in the Kofiau MPA was different-small reef fish density did not increase and the catch of small reef fish declined from the base levels. However, catch of small reef fish increased in the Kofiau spillover region under all scenarios. The opposite result was observed in the Misool spillover region-the catch did not increase in any scenario. The results indicate that fishing mortality outside the reserve affected rebuilding and catch inside the MPA. Catch and biomass density inside the MPAs were explained by the difference in spillover catch from Kofiau MPA versus Misool MPA.

The trade-off was not apparent in Dampier Strait. The spillover catch was higher than baseline under status quo, no commercial, and no destructive fishing scenarios, but the catch levels were similar in these scenarios and did not increase with increasing fishing restrictions. When destructive fishing was restricted, the biomass density and catch of small reef fish increased inside the MPA. When all fisheries were restricted in Dampier Strait, large reef fish and medium reef fish biomass density increased, the increase predation pressure on small reef fish was probably responsible for the decline in catch within the spillover.

\section{Discussion}

4.1. Reef Fish Biomass Density inside MPA. The functional groups in the model with low dispersal rates responded most to protection from MPAs. Other researchers have made similar observations [65-68]. The exchange rate across MPA boundaries is recognized as an important characteristic according to both empirical [69] and other modelling studies $[11,49]$ in determining the success of the MPA. Speciesspecific or functional group-specific dispersal rates are not very well known. The uncertainty in the dispersal rates used in the Ecospace model therefore has huge implications on the application of model results to the real world. While some researchers have found that dispersal rates might 


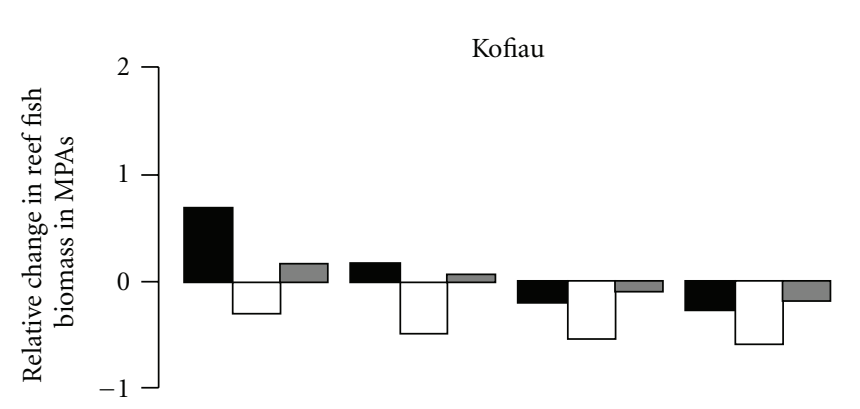

(a)

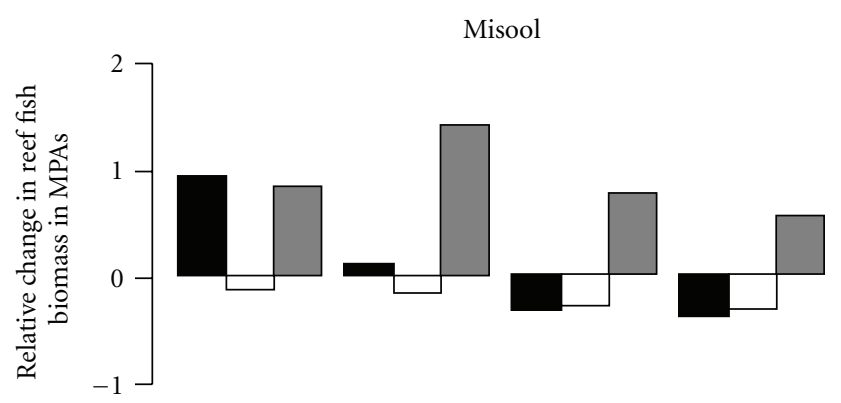

(b)

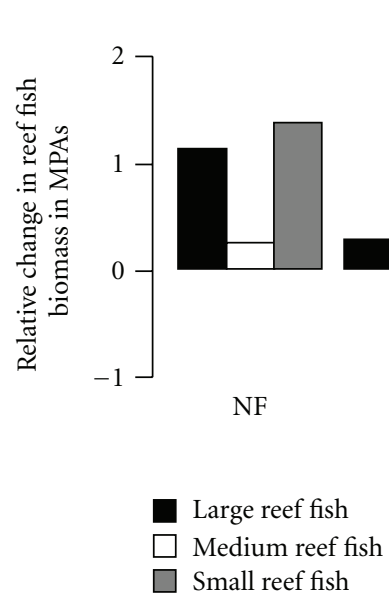

(c)

Figure 3: Relative biomass density changes inside the three analysed MPAs after 20-year simulation using Ecospace model. The graphs show the change in biomass relative to the base (2005) biomass of large, medium, and small reef fish. The fishing restriction scenarios are shown on the horizontal axis: NF: no fishing, NC: no commercial, ND: no destructive, and SQ: status quo. Black bars represent large reef fish, white bars represent medium reef fish, and grey bars represent small reef fish.

be approximated by flow characteristics and reef geomorphology [70], others studies have not found correlations with environment and hydrographic variables [71]. Other studies have related dispersal to "pelagic larval duration" [72, 73] or extent of relatively homogenous (genetically) metapopulations [74]. Relating dispersal rate to life history [75] would be highly opportune from a modelling perspective. This is a highly vibrant field and the increasing depth in understanding of dispersal will help build better models and improve development of spatial management guidelines. In comparison to reef fish species relatively less information was available on dispersal of nonreef fish populations, and in this paper the Raja Ampat Ecospace model was used in this paper to evaluate the impacts on reef fish populations. In order to use the Raja Ampat model for a similar evaluation of MPA benefits, especially for nonreef fish populations, the authors recommend that the dispersal rates be revisited and improved based on reviews [76] or more recent estimations of dispersal rates. Incorporating a sensitivity analysis on the dispersal rates in Ecospace will lead to a better understanding of the implications of the uncertainty on the results and monitoring existing, and experimental closures will increase understanding of actual dispersal rates [68]. It is clear that for more mobile organisms, the optimum size for closed area increases. There is thus no "one" optimum size for an MPA; the decision on size depends on the major species for which the protection is aimed. Costello et al. [77] showed that improved information on dispersal rates of species could increase the size of closures and improve zoning between habitat closures and fished areas. New approaches designed to protect far-ranging pelagic species include protecting demographically critical areas where the populations have higher vulnerability [78] or temporary spatial closures with the location of the closed areas changing during the course of the year [79].

In Ecospace, the larvae are assumed to recruit to the same location as adults; thereafter the dispersal rates determine the spread of the larvae into adjacent cells. Since many of our reef fish groups were aggregated, we were not able to differentiate very well between responses of different species of juveniles and are able to predict only overarching responses. Juveniles showed lower rebuilding than adults because even under protection scenarios juveniles experienced predation from adult reef fish groups in the model. Even when the juveniles are only a small portion of the diet of the adults, the larger biomass density of the adults combined with the rebuilding effect of MPAs on adults resulted in maintenance of the predation pressure on juveniles. Migration in and out of the 


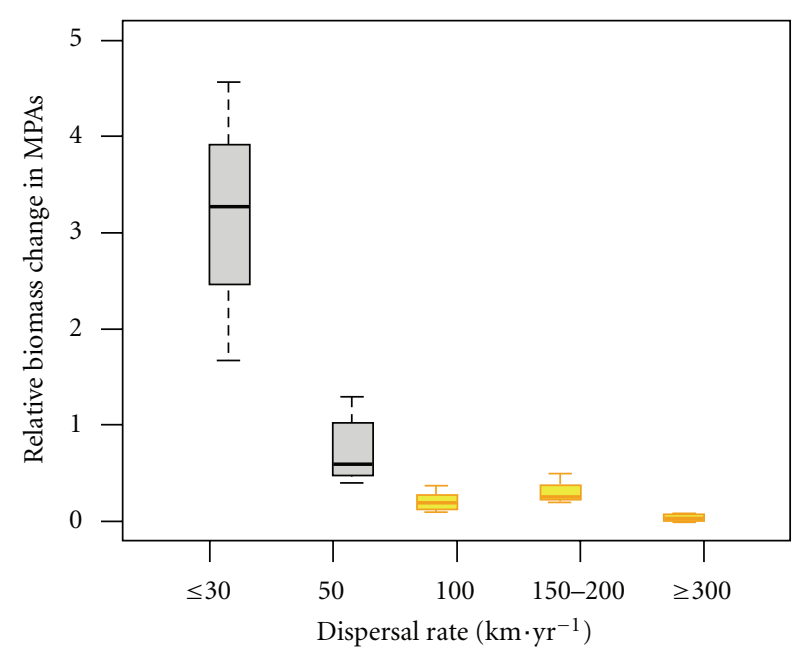

(a)

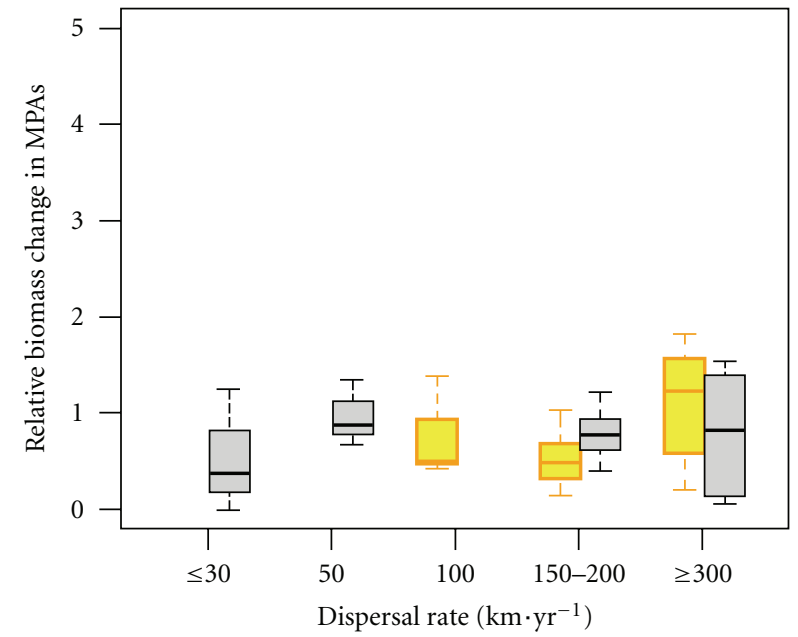

(c)

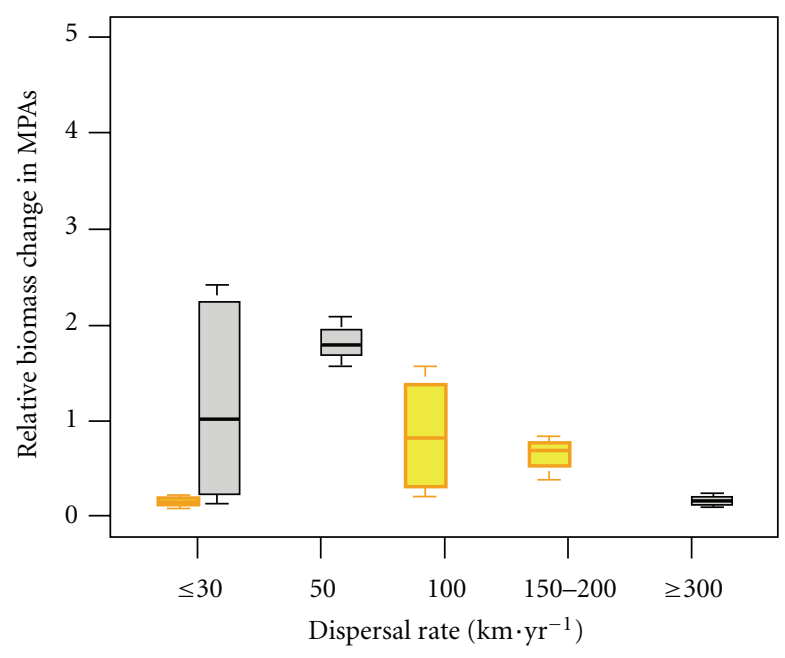

(b)

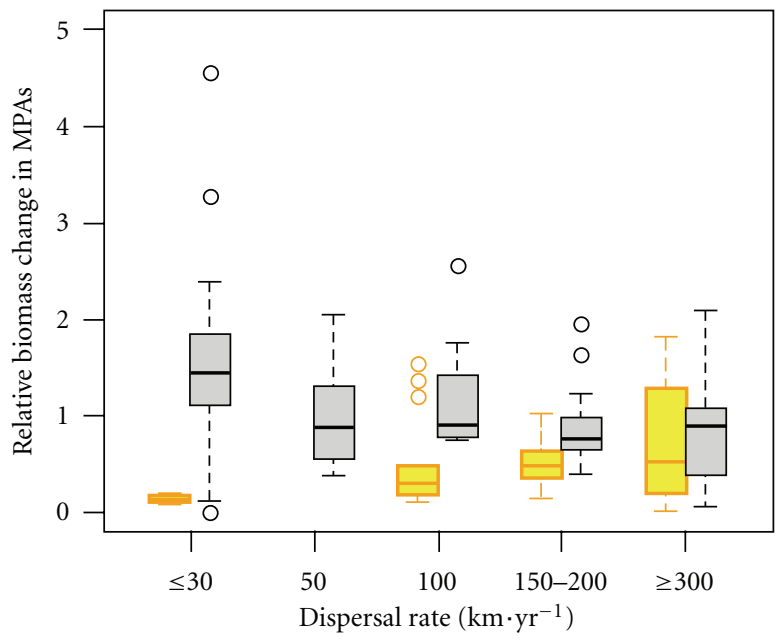

(d)

FIGURE 4: Influence of dispersal rate on biomass density change. The relative change in biomass of fish functional groups obtained in the three analysed MPAs after 20-year simulation using Ecospace model under no fishing scenario was combined and grouped into five classes according to the dispersal rates (shown on $x$ axis). The four panels group the functional groups by trophic level ((a) 2-2.5; (b) 2.5-3; (c) 3-3.5; (d) >3.5) Box plots (grey: adults and yellow: juveniles) are drawn to show the range in biomass change.

system is handled implicitly by the ecotrophic efficiency term [37], which effectively describes the amount of mortality incurred outside of the system. Portions of the diets of migrating species can be classified as import such that the energy from within the system is used only partially by the migrating species. EwE assumes that growth rate within and outside are the same [38]; thus dynamics outside the modelled area do not influence the population dynamics within the model (except in cases where such influences are explicitly modelled using forcing functions [80-82]).

The increase in biomass density of large reef fish inside the MPA depressed the population of medium reef fish leading to an increase in biomass density of small reef fish. The trophic cascade in MPAs has also been reported in other studies using Ecospace [66] with high predator densities and low prey densities inside the MPA. A comparison of unfished reef versus fished reefs has shown that a larger population of higher trophic level species "overwhelmed the fish assemblages so that the biomass pyramid was inverted" [83]. A review of empirical studies documents several cases where increase in dominance of larger predatory species was observed [16]. When all fisheries were restricted, medium reef fish did not increase above the base levels; however, the biomass density was higher than when all fisheries were allowed. Trophic cascades could be a reason why population increases of midtrophic level species in an MPA may be moderate. Midtrophic level species will respond to protection when the release from fishing pressure is greater than the increase in predation pressure under MPA protection. However, changes in size structure of midtrophic level species due to reduced fishing pressure in an MPA could offset the "negative impacts of enhanced predation" [24]. 

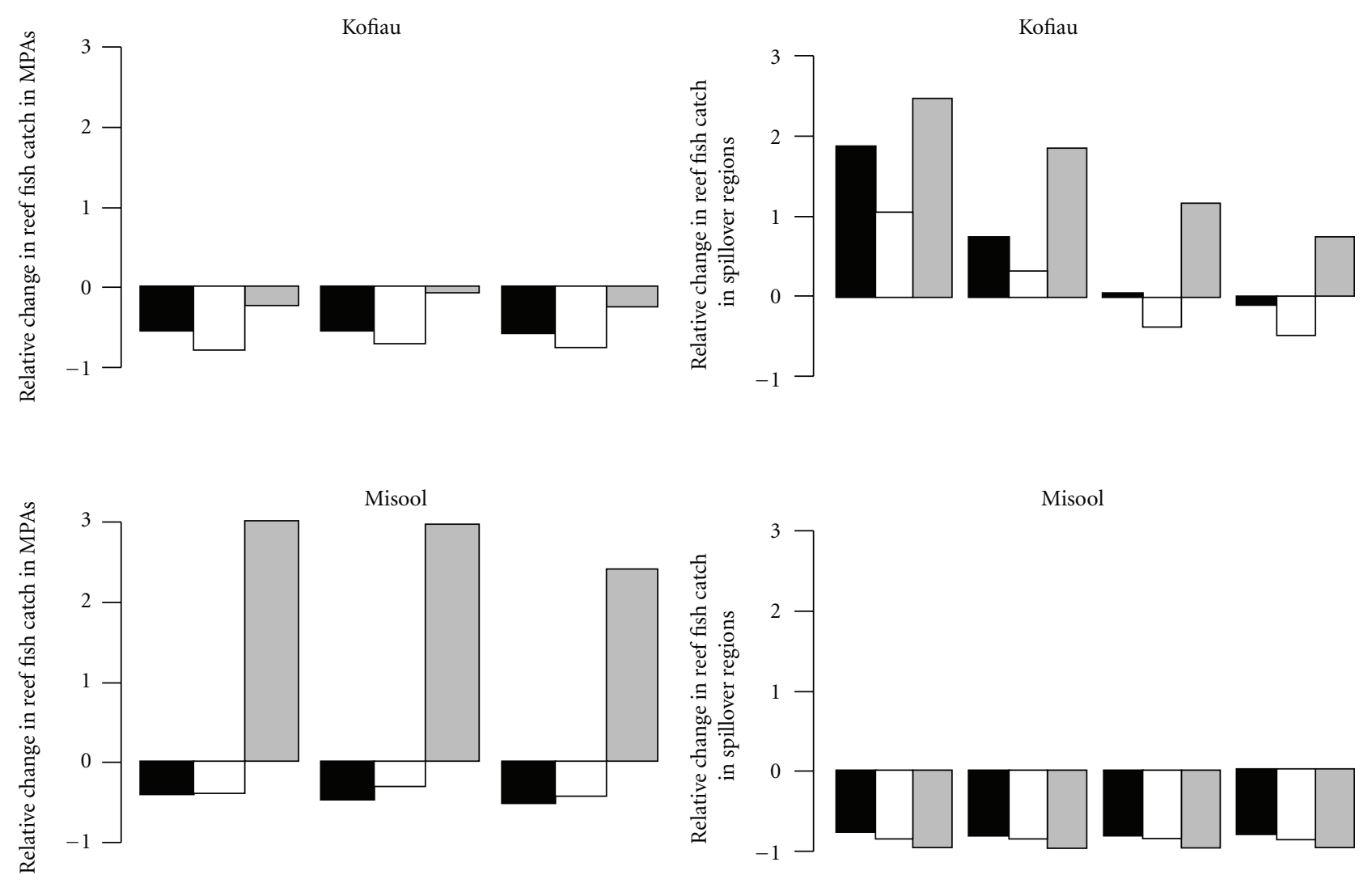

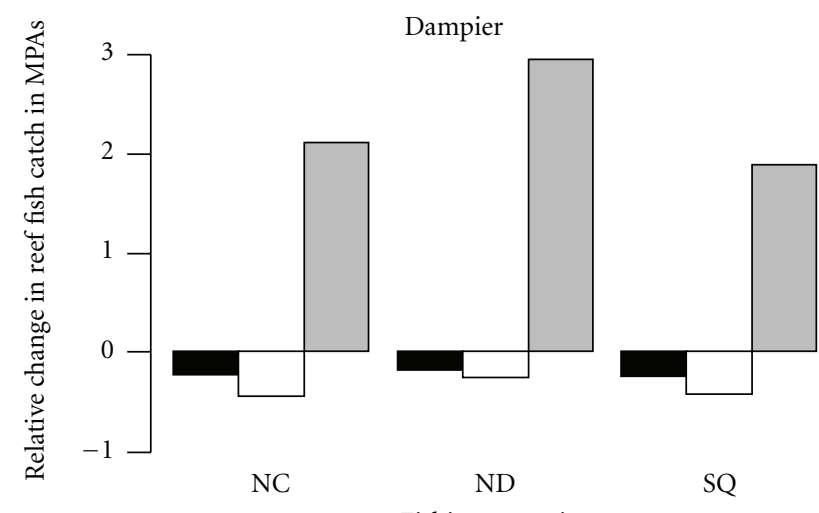

Fishing scenarios

Large reef fish

Medium reef fish

Small reef fish

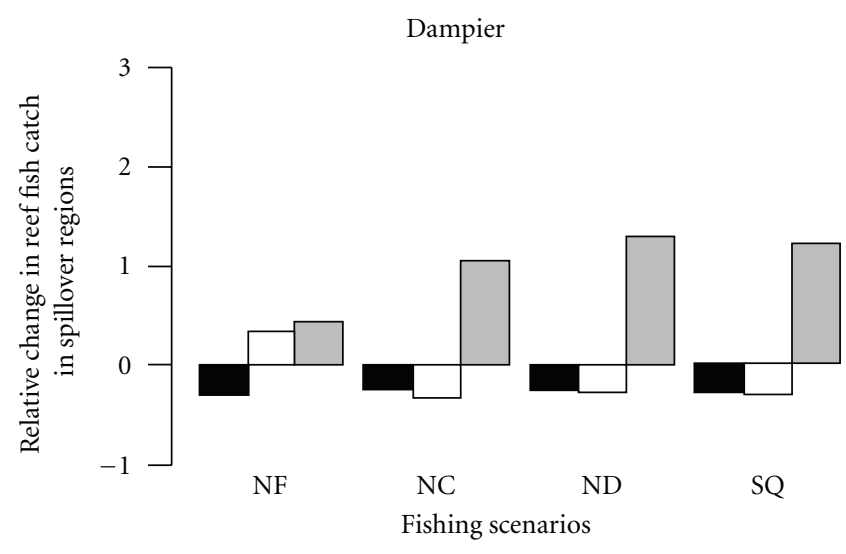

Large reef fish

$\square$ Medium reef fish

$\square$ Small reef fish

(a)

(b)

FIGURE 5: Relative catch changes inside the three analysed MPAs and spillover regions after 20-year simulation using Ecospace model. The bars show the change in catch relative to the base (model initialization for 2005) catch of large, medium, and small reef fish inside the MPAs (left panel) and spillover (right panel) under fishing restriction scenarios shown on horizontal axis: NF: no fishing, NC: no commercial fishing, ND: no destructive fishing, and SQ: status quo fishing. Black bars represent large reef fish, white bars represent medium reef fish, and grey bars represent small reef fish. 
4.2. Reef Fish Catch inside MPA and inside Spillover Regions. Another clear result from the Ecospace analysis was that a no-take area was needed for rebuilding the population. Compared to partial fishing restrictions, the increases in biomass density observed when the MPAs were set as notake were much higher. A similar result was obtained in an analysis of dolphin populations in Ionian Sea-when no fishing was allowed, rebuilding of dolphin populations occurred, but the dolphin populations showed only a small increase when the artisanal fisheries were allowed [66]. It has been suggested that higher fishing effort in the spillover region encourages spillover [84], implying that fisheries adjacent to an MPA can drain the MPA of the rebuilding fish biomass [65]. Among the three spillover regions compared, the relative increase in fishing effort in the spillover region was highest in Kofiau-the same MPA showed lowest levels of rebuilding. Spillover fisheries have also been referred to as "fishing the line" and have been found to have implications on the density of fish inside the reserve, especially on the boundary of the MPA [85]. This effect is predominant when the no-take areas are small [86-88] or when the target species are highly mobile $[85,89]$.

We have discussed the overarching patterns but we were unsuccessful in describing the reasons for several observations (e.g., increase in biomass density of medium reef fish in Dampier Strait MPA). This is probably because different habitat distributions between the MPAs combined with dispersal rates lead to differences in predator-prey interactions causing variation in biomass dynamics. Fish catch was a combined result of spatially varying biomass dynamics; fishing effort is thus dependent on how well the assumption of ideal free distribution represents real fishing effort distribution. If it is expected that fishers from different villages differ in their preference for distance travelled, more realistic predictions would probably be obtained by mapping fishing grounds from each fishing village [90].

From a management perspective, the main finding is that no-take areas are essential for rebuilding. In cases where spillover catch increases (e.g., Kofiau), it would be appropriate to establish no-take areas; in order to be successful the placement of these zones would probably need to accommodate spatial property rights [91]. Where spillover catch does not increase (e.g., Misool), establishing a notake regulation may not be viable. Spillover is expected to be limited when the MPA boundary follows the habitat boundary [15]; this could be a reason for the observation in Misool spillover region. The succeeding research question would be regarding the minimum size of individual notake areas that permit rebuilding while compromising for spillover fisheries.

\section{Conclusion and Management Implications}

The results have implications on MPA design-whether a buffer zone should be placed between the closed (no-take) and open areas. Spillover would depend on the type of fisheries allowed in the buffer zone and the trophic cascade effects. If the buffer zone fisheries are, for example, artisanal hook and line fisheries, then they might target only the top predator species in the buffer zone and not dilute the spillover of other reef fish and pelagic fish. More modelling effort is needed to understand whether buffer zones would enhance or dilute the spillover effects. It might be possible to design MPA zoning in concordance with the dispersal rate of species (e.g., [112]). Additionally, very selective gears might be allowed in the respective buffer zones. Spillover from a reserve would also depend on distance from the reserve [113], on nonfisheries aspects like tidal flow and reef morphology [69], and on whether fishers enter the spillover habitat area and find it suitable to fish [114].

Success of MPAs will depend on "understanding of the spatial structure of impacted fisheries and ecosystems" as stated in [115] and echoed 5 years later by [116]. Rapid rebuilding of reef fish populations requires no-take areas. When some forms of fishing are allowed inside the MPA, rebuilding is a slower process, especially for the larger reef fish species. Higher fishing effort in the spillover region encourages spillover [84], but high spillover could drain the MPA of the rebuilding fish biomass [65]. Benefits of rebuilding fish populations, partially operating fisheries, and spillover across the MPA boundaries each will be differently favoured by different MPA designs.

\section{Appendices}

\section{A.}

Extended summary of data sources (excerpt from [34] and [35]).

A.1. Raja Ampat Ecopath with Ecosim Model. The Raja Ampat model describes the region from $129^{\circ} 12^{\prime} \mathrm{E}$ and $0^{\circ} 12^{\prime}$ $\mathrm{N}$ to $131^{\circ} 30^{\prime} \mathrm{E}$ and $2^{\circ} 42^{\prime} \mathrm{S}$. This large-scale model includes all the waters of Raja Ampat. The functional groups represent reef-associated fish identified by McKenna et al. [25], as well as pelagic and deepwater fish occurring in Eastern Indonesia. In order to be included in the model, a fish species had to be listed in Fishbase (FB) [42] both under the "Indonesia" country code (FB country code 360 ) and the "Papua New Guinea" code (FB country code 598). That information is found on the "DemersPelag" (habitat) field of the "Species" table in the FB database.

A.2. Functional Group Designations. Ninety-eight functional groups are used to represent the marine ecosystem of Raja Ampat. These include mammals, birds, reptiles, fish, invertebrates, plants, zooplankton, phytoplankton, and nonliving groups such as fishery discards and organic detritus. Highorder food web dynamics are carefully represented in the Ecopath with Ecosim (EwE) models in order to provide reliable forecasts concerning the impacts of fisheries on coral reefs. Important predatory, herbivorous, and commercial fish tend to be allotted into highly specialized functional groups, while basal organisms are generally aggregated. At 98 functional groups these are complex models, but we believe that this approach is necessary in order to provide sufficient resolution to capture important processes occurring on coral reefs. 
A.3. Fish Functional Groups. Because of the enormous amount of differentiation in life-history, morphology, and feeding guilds that appears within coral reef fish families, delineating functional groups by fish family is impractical and may be unwise. Through evolutionary convergence, similar niche specializations can be present in unrelated taxa; or a single fish family may include multiple functional niches. The specific group structure in a EwE model is largely subjective and should be tailored to satisfy specific requirements of the investigation. Therefore, most of the functional groups developed for the preliminary Raja Ampat ecosystem models are based on the functional role that the fishes play in the ecosystem, with additional groups configured to allow the representation of important commercial, social, and ecological interests. The important specializations were determined based on the ecological literature available for coral reef ecosystems (e.g., Bellwood et al. [17]) and through expert communication.

There are 1203 fish species represented in the RA model. The common and scientific name of each species is presented in Table A.1.1 in Ainsworth et al. [34] along with their assigned functional group. The fish species are apportioned into 57 functional groups, of which 30 represent unique species or species groups. The remaining functional groups correspond to various juvenile, subadult, and adult life history stages included in the model to represent ontogenetic feeding, mortality, and behaviour.

Fish functional groups may be designed to represent specific functional roles (e.g., grooming by cleaner wrasse, algae mediation by herbivorous echinoids), to represent species of commercial interest (e.g., skipjack tuna, groupers), or to cover the wide diversity of fishes in aggregated species groups (e.g., large reef-associated fish). Fish have been allocated into functional groups based also on body size (e.g., small, medium, and large groups), feeding guild (e.g., planktivorous and piscivorous), and habitat (e.g., pelagic, demersal, reef-associated). The rationale behind functional group designation is provided in Table A.3.1 in Ainsworth et al. [34].

A.4. Basic Parameterization. The data needs of Ecopath can be summarized as follows. Four data points are required for each functional group: biomass (in $\mathrm{t} \cdot \mathrm{km}^{-2}$ ), the ratio of production over biomass $\left(\mathrm{P} / \mathrm{B}\right.$; in $\left.\mathrm{yr}^{-1}\right)$, the ratio of consumption over biomass $\left(\mathrm{Q} / \mathrm{B}\right.$; in $\left.\mathrm{yr}^{-1}\right)$, and ecotrophic efficiency (EE; unitless). Ecopath also provides an input field representing the ratio of production over consumption (P/Q; unitless), which users may alternatively use to infer either $\mathrm{P} / \mathrm{B}$ or $\mathrm{Q} / \mathrm{B}$ based on the other. Each functional group requires 3 out of 4 of these input parameters, and the remaining parameter is estimated using the mass-balance relationship [38]. A biomass accumulation rate may be entered optionally; the default setting assumes a zero-rate instantaneous biomass change. $\mathrm{P} / \mathrm{B}$ was determined based on the sum of the natural mortality rate $(\mathrm{M})$, estimated using the empirical formula of Pauly [117], and some fishing mortality rate $(\mathrm{F})$, which is an assumed fraction of $\mathrm{M}$. As a guideline, heavily exploited species were assumed to have an $\mathrm{F}$ approximately equal to $\mathrm{M}$, while moderately exploited species were assumed to have an $\mathrm{F}$ equal to $\mathrm{M} / 2$ or less. Q/B was taken preferentially from the literature or as estimated in FB. Estimates of $Q / B$ s from $F B$ sources were accepted if the data is based on a study of similar temperature to Raja Ampat $\left(28^{\circ} \mathrm{C} \pm 2^{\circ} \mathrm{C}\right)$. For each fish species, the $\mathrm{Q} / \mathrm{B}$ value was taken directly from FB, if available from the "PopQB" field of the "QB" table. Otherwise, an empirical relationship based on feeding mode [118] Pauly (1986) was used to estimate Q/B for each species.

\section{A.5. Data Sources.}

A.5.1. Biomass. Where possible, reef health monitoring data is used to set the biomass of fish functional groups directly. Recent biomass data is obtained from reef health monitoring studies around the Kofiau and Boo Island groups (A. Muljadi. TNC-CTC. Jl Gunung Merapi No. 38, Kampung Baru, Sorong, Papua, Indonesia 98413. Email: amuljadi@tnc.org. Unpublished data) and Misool Islands (M. Syakir. TNCCTC. Jl Gunung Merapi No. 38, Kampung Baru, Sorong, Papua, Indonesia 98413. Email: msaykir@tnc.org. Unpublished data). Reef health monitoring studies conducted snorkeling and SCUBA transects in monitoring sites selected by a stratified random approach after the methodology of Jolly and Hampton [119] (see [120]). Transect sites in Kofiau and Weigeo were selected randomly with replacement from among a population of sites that occur at $3 \mathrm{~km}$ intervals along the coast line. One-third of the sites were selected for examination. This is an intensive sampling regime compared with previous TNC efforts in Komodo National Park [120]. Five dive transects are conducted at each site monitored. Herbivorous fish are counted at 4 and $8 \mathrm{~m}$ depth. For herbivores $>40 \mathrm{~cm}$ tail length (TL), the family is also recorded as surgeonfish (Acanthuridae), rabbitfish (Siganidae), or parrotfish (Scaridae). Piscivorous fish are counted at $12 \mathrm{~m}$ depth. The divers searched for 8 piscivore families, but representatives from only 5 were recorded in Kofiau: Carangidae, Serranidae, Lutjanidae, Scombridae, and Sphyraenidae. Body lengths and abundance recorded in transect studies were converted to biomass density estimates by calculating the total body weight of observed individuals using length-weight $(\mathrm{L} / \mathrm{W})$ relationships and dividing the biomass by the area scanned in the transect. For several functional groups where this data was not available, biomass density estimates based on COREMAP [43] Raja Ampat reef transect data were used.

A.5.2. Diet. In November and December 2006 an analysis of fish gut contents was conducted in Raja Ampat by CI staff and two students from the State University of Papua (contact: Christovel Rotinsulu. CI. Jl.Gunung Arfak.45.Sorong, Papua, Indonesia. Email: chris@conservation.or.id). The protocol for obtaining samples, dissecting stomachs, and analyzing the results is presented in Appendix C.2 of Ainsworth et al. [34]. Briefly, fish were purchased at markets and the stomachs removed, or else fishers were paid a fee in order to extract the stomachs. Stomachs were preserved in formalin and later dissected in the lab. Prey items were weighed and identified to the species or family level. The diets of 
predator fish families are converted to percent composition values and scaled to total $100 \%$. Assumptions made while converting components to percentages are as follows: fish included in the diets of several species were listed as small coral fish. We therefore split the fish component into the following groups: large reef associated (20\%), medium reef associated (20\%), small reef associated (30\%), macroalgal browsers (10\%), eroding grazers $(10 \%)$, and scraping grazers $(10 \%)$. Entries for shrimp were divided equally between the two shrimp groups, "penaeid shrimps" and "shrimps and prawns". There were sand and coral fragments in the diet of several families of fish sampled. Half of this amount was assumed to be biogenic, originating from the hard coral functional group "Hermatypic scleractinian corals"; the other half was assumed to be sand and was omitted from the diet matrix. We assumed that those species that ate hard coral would also eat soft coral and nonreef building scleractinian corals. We assumed that those species would eat about half as much of soft coral and nonreef building coral. Entries for unidentifiable brown liquid were omitted from the diet composition. For functional groups where stomach sampling data was not available, a diet algorithm was used. The algorithm determined likely prey species for each predator based on habitat cooccupation and gape size/body depth limitations, determined the fractional contribution of each prey species according to a size-based vulnerability function, and aggregated the values to produce a predator-prey diet matrix at the functional group level.

A.5.3. Fisheries. The preliminary gear types included in the RA model were selected based on discussions with local fisheries experts and on Indonesian fishery records and publications (Departemen Pertanian. Jakarta; Subani and Barus, 1989; Andreas Muljadi, Obed Lense, Reinhart Poat, Arif Pratomo. TNC-CTC. Jl Gunung Merapi No. 38, Kampung Baru, Sorong, Papua, Indonesia 98413. Personal communication). This information was then updated using local surveys conducted by TNC and CI.

A.5.4. Fisheries: Aerial Survey. TNC field teams conducted the aerial survey of fishing effort in Raja Ampat. The survey was conducted in two phases; the first was from January 9 to 13, 2006; the second was from October 18 to 22, 2006. There were 10 flights in each phase to cover all the waters of Raja Ampat. The survey recorded the following point features: vessels (transport, fishing, industrial, tourist, others, unknown), fish cages, fishing shelters, fish platforms, FADs (rumpon), whales, dolphins, manta, dugong, and tuna feeding/bait schools. The size of the vessels, the type of engine, and the type of activity the vessels were engaged in were also noted. The results from the aerial survey were used as an input in estimating the IUU catches, and hence this data contributed to the improvement of the catch matrix in the model. Protocol for the aerial photography survey is provided in Mous [121]; highlights of the aerial survey results are provided in Barmawi [122]. An online interactive map is available to access the georeferenced aerial photography (http://www.rajaampat.org/); alternatively, a two-DVD set of photographs is available through the TNC Bali office (contact: Joanne Wilson, TNC CTC. Jl Pengembak 2, Sanur, Bali, Indonesia joanne_wilson@tnc.org).

A.5.5. Fisheries: Resource Use Survey. The resource use survey for Kofiau island in Raja Ampat was conducted by TNC field team for Raja Ampat (Andreas Muljadi. TNC-CTC. Jl Gunung Merapi No. 38, Kampung Baru, Sorong, Papua, Indonesia 98413. Unpublished data). The survey consisted of a mobile monitoring team that travelled by boats to the fishing villages around the Kofiau island and also intercepted fishers in the waters around Kofiau. The survey was conducted on 8 days between December 2005 and July 2006. The marine area around Kofiau was divided into 6 sectors totaling an area of $2350 \mathrm{~km}^{-2}$ (the average area of each sector: $390 \mathrm{~km}^{-2}$ ). The survey collected information on number and names of vessels observed, the type of activity they were engaged in, the engine types, and the gears used when the vessels were found fishing. They also noted the composition and quantity of the fish catch. In addition to monitoring vessels, the survey also monitored fixed gears that included karambas (floating net cages) and temporary huts on water.

A.5.6. Fisheries: Coastal Rural Appraisal Survey. A coastal rural appraisal was conducted by TNC in 22 villages across Kofiau and Misool Islands of Raja Ampat in 2004 [31]. Villagers were interviewed about their education, health, their source of livelihood (fisheries), and the threats to the livelihood sources. The report provided valuable information about target species, the different types of gears, and gear use in the communities. A similar survey was conducted by Conservation International across Raja Ampat to update the information on fisher population in Raja Ampat.

\section{Acknowledgments}

The work is the result of a science-based initiative- the Birds Head Seascape Ecosystem-Based Management projectfunded by the David and Lucille Packard Foundation. The project involved field study and ecological modelling with The Nature Conservancy (TNC), Conservation International (CI), and World Wildlife Fund (WWF). The authors acknowledge their partners, especially Peter Mous (COREMAP II), Joanne Wilson, Mohd. Barmawi, Jos Pet Yohannes Goram and Anotn Suebo, Andres Muljadi, Rein Paat, Obed Lense, Mohd. Syakir (TNC Coral Triangle Centre), Mark Erdmann, and Chris Rotinsulu (CI). They acknowledge Becky Rahawarin (Kepala Dinas Perikanan dan Kelautan, Raja Ampat) for helpful discussions. D. Varkey also acknowledges University Graduate Fellowship from UBC. Special thanks to Dr. Andrew Rosenberg (Conservation International) for extremely valuable feedback on an earlier version of the paper. They also acknowledge Rajeev Kumar for helping with analysis of the results using SAS software. They also thank their anonymous reviewers for detailed and constructive comments on the earlier paper draft. 


\section{References}

[1] J. M. Pandolfi, R. H. Bradbury, E. Sala et al., "Global trajectories of the long-term decline of coral reef ecosystems," Science, vol. 301, no. 5635, pp. 955-958, 2003.

[2] F. R. Gell and C. M. Roberts, "Benefits beyond boundaries: the fishery effects of marine reserves," Trends in Ecology and Evolution, vol. 18, no. 9, pp. 448-455, 2003.

[3] S. K. Hooker and L. R. Gerber, "Marine reserves as a tool for ecosystem-based management: the potential importance of Megafauna," BioScience, vol. 54, no. 1, pp. 27-39, 2004.

[4] B. S. Halpern, "The impact of marine reserves: do reserves work and does reserve size matter?" Ecological Applications, vol. 13, no. 1, pp. S117-S137, 2003.

[5] G. R. Russ and A. C. Alcala, "Marine reserves: rates and patterns of recovery and decline of predatory fish, 19832000," Ecological Applications, vol. 13, no. 6, pp. 1553-1565, 2003.

[6] A. C. Alcala and G. R. Russ, "No-take marine reserves and reef fisheries management in the Philippines: a new people power revolution," Ambio, vol. 35, no. 5, pp. 245-254, 2006.

[7] A. Bartholomew, J. A. Bohnsack, S. G. Smith, J. S. Ault, D. E. Harper, and D. B. McClellan, "Influence of marine reserve size and boundary length on the initial response of exploited reef fishes in the Florida Keys National Marine Sanctuary, USA," Landscape Ecology, vol. 23, no. 1, pp. 55-65, 2008.

[8] M. Schrope, "Conservation: providential outcome," Nature, vol. 451, no. 7175, pp. 122-123, 2008.

[9] S. E. Lester, B. S. Halpern, K. Grorud-Colvert et al., "Biological effects within no-take marine reserves: a global synthesis," Marine Ecology Progress Series, vol. 384, pp. 33-46, 2009.

[10] H. Jiang, H. Q. Cheng, W. J. F. Le Quesne et al., "Ecosystem model predictions of fishery and conservation trade-offs resulting from marine protected areas in the East China Sea," Environmental Conservation, vol. 35, no. 2, pp. 137-146, 2008.

[11] L. R. Little, A. E. Punt, B. D. Mapstone, G. A. Begg, B. Goldman, and N. Ellis, "Different responses to area closures and effort controls for sedentary and migratory harvested species in a multispecies coral reef linefishery," ICES Journal of Marine Science, vol. 66, no. 9, pp. 1931-1941, 2009.

[12] J. Claudet, D. Pelletier, J. Y. Jouvenel, F. Bachet, and R. Galzin, "Assessing the effects of marine protected area (MPA) on a reef fish assemblage in a northwestern Mediterranean marine reserve: identifying community-based indicators," Biological Conservation, vol. 130, no. 3, pp. 349-369, 2006.

[13] T. R. McClanahan, N. A. J. Graham, J. M. Calnan, and M. A. MacNeil, "Toward pristine biomass: reef fish recovery in coral reef marine protected areas in Kenya," Ecological Applications, vol. 17, no. 4, pp. 1055-1067, 2007.

[14] P. P. Molloy, I. B. McLean, and I. M. Côté, "Effects of marine reserve age on fish populations: a global meta-analysis," Journal of Applied Ecology, vol. 46, no. 4, pp. 743-751, 2009.

[15] S. D. Gaines, C. White, M. H. Carr, and S. R. Palumbi, "Designing marine reserve networks for both conservation and fisheries management," Proceedings of the National Academy of Sciences of the United States of America, vol. 107, no. 43, pp. 18286-18293, 2010.

[16] J. A. García-Charton, A. Pérez-Ruzafa, C. Marcos et al., "Effectiveness of European Atlanto-Mediterranean MPAs: do they accomplish the expected effects on populations, communities and ecosystems?" Journal for Nature Conservation, vol. 16, no. 4, pp. 193-221, 2008.
[17] D. R. Bellwood, T. P. Hughes, C. Folke, and M. Nyström, "Confronting the coral reef crisis," Nature, vol. 429, no. 6994, pp. 827-833, 2004.

[18] S. Jennings, E. M. Grandcourt, and N. V. C. Polunin, "The effects of fishing on the diversity, biomass and trophic structure of Seychelles' reef fish communities," Coral Reefs, vol. 14, no. 4, pp. 225-235, 1995.

[19] S. Jennings and N. V. C. Polunin, "Effects of fishing effort and catch rate upon the structure and biomass of Fijian reef fish communities," Journal of Applied Ecology, vol. 33, no. 2, pp. 400-412, 1996.

[20] S. Jennings and N. V. C. Polunin, "Impacts of predator depletion by fishing on the biomass and diversity of nontarget reef fish communities," Coral Reefs, vol. 16, no. 2, pp. 71-82, 1997.

[21] E. Sala, C. F. Boudouresque, and M. Harmelin-Vivien, "Fishing, trophic cascades, and the structure of algal assemblages: evaluation of an old but untested paradigm," Oikos, vol. 82, no. 3, pp. 425-439, 1998.

[22] S. E. Swearer, J. E. Caselle, D. W. Lea, and R. R. Warner, "Larval retention and recruitment in an island population of a coral-reef fish," Nature, vol. 402, no. 6763, pp. 799-802, 1999.

[23] T. P. Hughes, M. J. Rodrigues, D. R. Bellwood et al., "Phase shifts, herbivory, and the resilience of Coral Reefs to climate change," Current Biology, vol. 17, no. 4, pp. 360-365, 2007.

[24] P. J. Mumby, C. P. Dahlgren, A. R. Harborne et al., "Fishing, trophic cascades, and the process of grazing on coral reefs," Science, vol. 311, no. 5757, pp. 98-101, 2006.

[25] S. A. McKenna, G. R. Allen, and S. Suryadi, A Marine Rapid Assessment of the Raja Ampat Islands, Papua Province, Indonesia, vol. 22, Conservation International, Washington, DC, USA, RAP Bulletin of Biological Assessment, 2002.

[26] R. Donnelly, D. Neville, and P. J. Mous, "Report on a rapid ecological assessment of the Raja Ampat Islands, Papua, Eastern Indonesia," The Nature Conservancy Coral Triangle Center. Indonesia. Final Draft, 2003.

[27] A. Halim and P. J. Mous, "Community perceptions of marine protected area management in Indonesia," $A$ report to National Oceanic and Atmospheric Administration (NOAA). The Nature Conservancy-Coral Triangle Center, vol. NA04NOS4630288, pp. 1-43, 2006.

[28] S. A. McKenna, P. Bolis, and G. R. Allen, "Condition of coral reefs at the Raja Ampat Islands, Papua Province, Indonesia," in A Marine Rapid Assessment of the Raja Ampat Islands, Papua Province, Indonesia, S. A. McKenna, G. R. Allen, and S. Suryadi, Eds., vol. 22, pp. 66-78, Conservation International, Washington, DC, USA, RAP Bulletin of Biological Assessment, 2002.

[29] Conservation International, "Environmental Friendly Development in Raja Ampat," 2008, http://www.conservation .or.id/home.php?catid=30\&tcatid=178\&page $=$ g-peluang.detail.

[30] Raja Ampat Regency, Bersama membangun Raja Ampat. Strategy, vision and mission statement of maritime Regency Raja Ampat, 2007.

[31] A. Muljadi, "Coastal rural appraisal report in Kofiau and Misool area of Raja Ampat Islands,” Tech. Rep., 2004.

[32] C. H. Ainsworth, T. J. Pitcher, and C. Rotinsulu, "Evidence of fishery depletions and shifting cognitive baselines in Eastern Indonesia," Biological Conservation, vol. 141, no. 3, pp. 848859, 2008. 
[33] C. H. Ainsworth, D. A. Varkey, and T. J. Pitcher, "Ecosystem simulations supporting ecosystem-based fisheries management in the Coral Triangle, Indonesia," Ecological Modelling, vol. 214, no. 2-4, pp. 361-374, 2008.

[34] C. H. Ainsworth, D. A. Varkey, and T. J. Pitcher, "Ecosystem simulation models for the Bird's Head Seascape, Papua ," in Ecological and Economic Analyses of Marine Ecosystems in the Birds Head Seascape, Papua, Indonesia, T. J. Pitcher, C. H. Ainsworth, and M. Bailey, Eds., vol. 15, pp. 6-172, Fisheries Centre Research Reports, 2007.

[35] C. H. Ainsworth, D. A. Varkey, and T. J. Pitcher, "Ecosystem simulation models of Raja Ampat, Indonesia, in support of ecosystem based fisheries management," in Ecological and Economic Analyses of Marine Ecosystems in the Birds Head Seascape, Papua, Indonesia, T. J. Pitcher, C. H. Ainsworth, and M. Bailey, Eds., vol. 16, pp. 3-122, Fisheries Centre Research Reports, 2008.

[36] V. Christensen and D. Pauly, "ECOPATH II-a software for balancing steady-state ecosystem models and calculating network characteristics," Ecological Modelling, vol. 61, no. 34, pp. 169-185, 1992.

[37] C. Walters, V. Christensen, and D. Pauly, "Structuring dynamic models of exploited ecosystems from trophic massbalance assessments," Reviews in Fish Biology and Fisheries, vol. 7, no. 2, pp. 139-172, 1997.

[38] V. Christensen and C. J. Walters, "Ecopath with Ecosim: methods, capabilities and limitations," Ecological Modelling, vol. 172, no. 2-4, pp. 109-139, 2004.

[39] C. Walters, D. Pauly, and V. Christensen, "Ecospace: prediction of mesoscale spatial patterns in trophic relationships of exploited ecosystems, with emphasis on the impacts of marine protected areas," Ecosystems, vol. 2, no. 6, pp. 539554, 1999.

[40] D. Pauly, V. Christensen, and C. Walters, "Ecopath, Ecosim, and Ecospace as tools for evaluating ecosystem impact of fisheries," ICES Journal of Marine Science, vol. 57, no. 3, pp. 697-706, 2000.

[41] M. Depczynski and D. R. Bellwood, "The role of cryptobenthic reef fishes in coral reef trophodynamics," Marine Ecology Progress Series, vol. 256, pp. 183-191, 2003.

[42] R. Freose and D. Pauly, "Fish base," World Wide Web electronic publication, 2010, http://www.fishbase.org.

[43] COREMAP, Penelitian Terumbu Karang Tingkat Lokal, Kab. Raja Ampat, Provinsi Irian Jaya Barat. Local level coral reef research in Raja Ampat, West Irian Jaya Province, 2005.

[44] DKP, “Laporan tahun 1994, 1998, 1999, 2002," Annual Reports, Departemen Kelautan dan Perikanan. Department of Marine Affairs and Fisheries, 1994-2002.

[45] M. Farid and D. Anggraeni, "Preliminary assessment of community-based natural resource management and conservation options in South Waigeo. Indonesia," Conservation International, Indonesia, 2003.

[46] D. A. Varkey, C. H. Ainsworth, T. J. Pitcher, Y. Goram, and R. Sumaila, "Illegal, unreported and unregulated fisheries catch in Raja Ampat Regency, Eastern Indonesia," Marine Policy, vol. 34, no. 2, pp. 228-236, 2010.

[47] T. J. Pitcher, E. A. Buchary, and T. Hutton, "Forecasting the benefits of no-take human-made reefs using spatial ecosystem simulation," ICES Journal of Marine Science, vol. 59, pp. 17-26, 2002.

[48] A. K. Salomon, N. P. Waller, C. Mcllhagga, R. L. Yung, and C. Walters, "Modeling the trophic effects of marine protected area zoning policies: a case study," Aquatic Ecology, vol. 36, no. 1, pp. 85-95, 2002.
[49] W. J. F. Le Quesne and E. A. Codling, "Managing mobile species with MPAs: the effects of mobility, larval dispersal, and fishing mortality on closure size," ICES Journal of Marine Science, vol. 66, no. 1, pp. 122-131, 2009.

[50] A. Firman and I. Azhar, "Atlas sumberdaya wilayah pesisir Kabupaten Raja Ampat, Provinsi Irian Jaya Barat. Atlas of the coastal area resources Raja Ampat Regency," Conservation International Indonesia Sorong, Indonesia, 2006.

[51] A. L. Shanks, B. A. Grantham, and M. H. Carr, "Propagule dispersal distance and the size and spacing of marine reserves," Ecological Applications, vol. 13, no. 1, pp. 159-169, 2003.

[52] P. W. Sammarco and J. C. Andrews, "Localized dispersal and recruitment in Great Barrier Reef corals: the helix experiment," Science, vol. 239, no. 4846, pp. 1422-1424, 1988.

[53] R. H. Richmond, "Energetics, competency, and long-distance dispersal of planula larvae of the coral Pocillopora damicornis," Marine Biology, vol. 93, no. 4, pp. 527-533, 1987.

[54] J. E. Bardach, "On the movements of certain Burmuda reef fishes," Ecology, vol. 39, no. 1, pp. 139-146, 1958.

[55] R. F. G. Ormond and M. A. Gore, "No-take zones: does behaviour matter? Aquatic telemetry. Advances and applications," in Proceedings of the 5th Conference on Fish Telemetry Held in Europe, vol. FAO/COISPA, pp. 71-89, Ustica, Italy, 1991.

[56] C. M. Roberts and N. V. C. Polunin, "Are marine reserves effective in management of reef fisheries?" Reviews in Fish Biology and Fisheries, vol. 1, no. 1, pp. 65-91, 1991.

[57] G. W. Barlow, "Patterns of parental investment, dispersal and size among coral-reef fishes," Environmental Biology of Fishes, vol. 6, no. 1, pp. 65-85, 1981.

[58] N. K. Jue, "Exploring the structure of genetic variation and the influences of demography on effective population size in the gag grouper Mycteroperca microlepi (Goode \& Bean)," Journal of Fish Biology, vol. 69, no. C, pp. 217-224, 2006.

[59] R. Fisher, "Swimming speeds of larval coral reef fishes: impacts on self-recruitment and dispersal," Marine Ecology Progress Series, vol. 285, pp. 223-232, 2005.

[60] C. Mora and P. F. Sale, "Are populations of coral reef fish open or closed?” Trends in Ecology and Evolution, vol. 17, no. 9, pp. 422-428, 2002.

[61] C. M. Roberts, "Connectivity and management of Carribean coral reefs," Science, vol. 278, no. 5342, pp. 1454-1457, 1997.

[62] S. J. D. Martell, T. E. Essington, B. Lessard, J. F. Kitchell, C. J. Walters, and C. H. Boggs, "Interactions of productivity, predation risk, and fishing effort in the efficacy of marine protected areas for the central Pacific," Canadian Journal of Fisheries and Aquatic Sciences, vol. 62, no. 6, pp. 1320-1336, 2005.

[63] S. A. Murawski, S. E. Wigley, M. J. Fogarty, P. J. Rago, and D. G. Mountain, "Effort distribution and catch patterns adjacent to temperate MPAs," ICES Journal of Marine Science, vol. 62, no. 6, pp. 1150-1167, 2005.

[64] V. Stelzenmüller, F. Maynou, G. Bernard et al., "Spatial assessment of fishing effort around European marine reserves: implications for successful fisheries management," Marine Pollution Bulletin, vol. 56, no. 12, pp. 2018-2026, 2008.

[65] R. Watson, J. Alder, and C. Walters, "A dynamic mass-balance model for marine protected areas," Fish and Fisheries, vol. 1, no. 1, pp. 94-98, 2000.

[66] C. Piroddi, An ecosystem-based approach to study two dolphin populations around the island of Kalamos, Ionian Sea, Greece, M.S. thesis, University of British Columbia, Canada, 2008. 
[67] A. Beattie, U. R. Sumaila, V. Christensen, and D. Pauly, "A model for the bioeconomic evaluation of marine protected area size and placement in the North Sea," Natural Resource Modeling, vol. 15, no. 4, pp. 413-437, 2002.

[68] V. Christensen, Z. Ferdaña, and J. Steenbeek, "Spatial optimization of protected area placement incorporating ecological, social and economical criteria," Ecological Modelling, vol. 220, no. 19, pp. 2583-2593, 2009.

[69] T. R. McClanahan and S. Mangi, "Spillover of exploitable fishes from a marine park and its effect on the adjacent fishery," Ecological Applications, vol. 10, no. 6, pp. 1792-1805, 2000.

[70] P. Cetina-Heredia and S. R. Connolly, "A simple approximation for larval retention around reefs," Coral Reefs, vol. 30, no. 3, pp. 593-605, 2011.

[71] À. López-Sanz, V. Stelzenmüller, F. Maynou, and A. Sabatés, "The influence of environmental characteristics on fish larvae spatial patterns related to a marine protected area: The Medes islands (NW Mediterranean)," Estuarine, Coastal and Shelf Science, vol. 92, no. 4, pp. 521-533, 2011.

[72] K. A. Selkoe and R. J. Toonen, "Marine connectivity: a new look at pelagic larval duration and genetic metrics of dispersal," Marine Ecology Progress Series, vol. 436, pp. 291305, 2011.

[73] A. L. Shanks, "Pelagic larval duration and dispersal distance revisited," Biological Bulletin, vol. 216, no. 3, pp. 373-385, 2009.

[74] P. Saenz-Agudelo, G. P. Jones, S. R. Thorrold, and S. Planes, "Connectivity dominates larval replenishment in a coastal reef fish metapopulation," Proceedings of the Royal Society B, vol. 278, no. 1720, pp. 2954-2961, 2011.

[75] I. R. Bradbury, B. Laurel, P. V. R. Snelgrove, P. Bentzen, and S. E. Campana, "Global patterns in marine dispersal estimates: the influence of geography, taxonomic category and life history," Proceedings of the Royal Society B, vol. 275, no. 1644, pp. 1803-1809, 2008.

[76] B. P. Kinlan and S. D. Gaines, "Propagule dispersal in marine and terrestrial environments: a community perspective," Ecology, vol. 84, no. 8, pp. 2007-2020, 2003.

[77] C. Costello, A. Rassweiler, D. Siegel, G. De Leo, F. Micheli, and A. Rosenberg, "The value of spatial information in MPA network design," Proceedings of the National Academy of Sciences of the United States of America, vol. 107, no. 43, pp. 18294-18299, 2010.

[78] E. T. Game, H. S. Grantham, A. J. Hobday et al., "Pelagic protected areas: the missing dimension in ocean conservation," Trends in Ecology and Evolution, vol. 24, no. 7, pp. 360-369, 2009.

[79] H. S. Grantham, S. L. Petersen, and H. P. Possingham, "Reducing bycatch in the South African pelagic longline fishery: the utility of different approaches to fisheries closures," Endangered Species Research, vol. 5, no. 2-3, pp. 291-299, 2008.

[80] L. J. Shannon, J. G. Field, and C. L. Moloney, "Simulating anchovy-sardine regime shifts in the southern Benguela ecosystem," Ecological Modelling, vol. 172, no. 2-4, pp. 269$281,2004$.

[81] S. Guénette, S. J. J. Heymans, V. Christensen, and A. W. Trites, "Ecosystem models show combined effects of fishing, predation, competition, and ocean productivity on Steller sea lions (Eumetopias jubatus) in Alaska," Canadian Journal of Fisheries and Aquatic Sciences, vol. 63, no. 11, pp. 2495-2517, 2006.
[82] S. K. Gaichas, K. Y. Aydin, and R. C. Francis, "What drives dynamics in the Gulf of Alaska? integrating hypotheses of species, fishing, and climate relationships using ecosystem modeling," Canadian Journal of Fisheries and Aquatic Sciences, vol. 68, no. 9, pp. 1553-1578, 2011.

[83] S. A. Sandin, J. E. Smith, E. E. DeMartini et al., "Baselines and degradation of coral reefs in the Northern Line Islands," PLoS One, vol. 3, no. 2, Article ID e1548, 2008.

[84] C. Walters, R. Hilborn, and C. Costello, "Comparison of marine protected area policies using a multispecies, multigear equilibrium optimization model (EDOM)," Fisheries Centre Working Paper, vol. 4, pp. 1-44, 2009.

[85] J. B. Kellner, I. Tetreault, S. D. Gaines, and R. M. Nisbet, "Fishing the line near marine reserves in single and multispecies fisheries," Ecological Applications, vol. 17, no. 4, pp. 1039-1054, 2007.

[86] J. L. Sánchez Lizaso, R. Goñi, O. Reñones et al., "Density dependence in marine protected populations: a review," Environmental Conservation, vol. 27, no. 2, pp. 144-158, 2000.

[87] E. H. A. Perez-Ruzafa, "Marine protected areas as a tool for fishery management and ecosystem conservation: an Introduction," ICES Journal of Marine Science, vol. 66, no. 1, pp. $1-5,2009$.

[88] J. Claudet, C. W. Osenberg, L. Benedetti-Cecchi et al., "Marine reserves: size and age do matter," Ecology Letters, vol. 11, no. 5, pp. 481-489, 2008.

[89] R. A. Abesamis and G. R. Russ, "Density-dependent spillover from a marine reserve: long-term evidence," Ecological Applications, vol. 15, no. 5, pp. 1798-1812, 2005.

[90] A. J. Scholz, C. Steinback, S. A. Kruse, M. Mertens, and H. Silverman, "Incorporation of spatial and economic analyses of human-use data in the design of marine protected areas," Conservation Biology, vol. 25, no. 3, pp. 485-492, 2011.

[91] S. Aswani and R. Hamilton, "The value of many small v. few large marine protected areas in the Western Solomon Islands," Traditional Marine Resource Management and Knowledge Information Bulletin, pp. 3-14, 2004.

[92] B. R. Mate, R. Gisiner, and J. Mobley, "Local and migratory movements of Hawaiian humpback whales tracked by satellite telemetry," Canadian Journal of Zoology, vol. 76, no. 5, pp. 863-868, 1998.

[93] K. Bilgmann, L. M. Möller, R. G. Harcourt, R. Gales, and L. B. Beheregaray, "Common dolphins subject to fisheries impacts in Southern Australia are genetically differentiated: implications for conservation," Animal Conservation, vol. 11, no. 6, pp. 518-528, 2008.

[94] C. H. Lockyer and S. G. Brown, "The migration of whales," in Animal Migration, D. J. Aidley, Ed., pp. 105-137, Cambridge University Press, Cambridge, UK, 1st edition, 1981.

[95] J. D. Miller, K. A. Dobbs, C. J. Limpus, N. Mattocks, and A. M. Landry Jr., "Long-distance migrations by the hawksbill turtle, Eretmochelys imbricata, from north-eastern Australia," Wildlife Research, vol. 25, no. 1, pp. 89-95, 1998.

[96] P. N. Lahanas, K. A. Bjorndal, A. B. Bolten et al., "Genetic composition of a green turtle (Chelonia mydas) feeding ground population: evidence for multiple origins," Marine Biology, vol. 130, no. 3, pp. 345-352, 1998.

[97] E. Naro-Maciel, J. H. Becker, E. H. S. M. Lima, M. Â. Marcovaldi, and R. DeSalle, "Testing dispersal hypotheses in foraging green sea turtles (Chelonia mydas) of Brazil," Journal of Heredity, vol. 98, no. 1, pp. 29-39, 2007. 
[98] S. Ferraroli, J. Y. Georges, P. Gaspar, and Y. Le Maho, "Where leatherback turtles meet fisheries," Nature, vol. 429, no. 6991, pp. 521-522, 2004.

[99] B. M. Gillanders, K. W. Able, J. A. Brown, D. B. Eggleston, and P. F. Sheridan, "Evidence of connectivity between juvenile and adult habitats for mobile marine fauna: an important component of nurseries," Marine Ecology Progress Series, vol. 247, pp. 281-295, 2003.

[100] M. Dorenbosch, M. C. Van Riel, I. Nagelkerken, and G. Van Der Velde, "The relationship of reef fish densities to the proximity of mangrove and seagrass nurseries," Estuarine, Coastal and Shelf Science, vol. 60, no. 1, pp. 37-48, 2004.

[101] B. C. Victor, "Duration of the planktonic larval stage of one hundred species of Pacific and Atlantic wrasses (family Labridae)," Marine Biology, vol. 90, no. 3, pp. 317-326, 1986.

[102] J. E. Graves, "Conservation genetics of fishes in the pelagic marine realm," in Conservation Genetics: Case Histories from Nature, J. C. Avise and J. L. Hamrick, Eds., pp. 335-366, Kluwer Academic Publishers, Mass, USA, 2nd edition, 1995.

[103] M. D. Santos, G. V. Lopez, and N. C. Barut, "A pilot study on the genetic variation of eastern little tuna (Euthynnus affinis) in Southeast Asia," Philippine Journal of Science, vol. 139, no. 1, pp. 43-50, 2010.

[104] J. P. Hoolihan, P. Anandh, and L. van Herwerden, "Mitochondrial DNA analyses of narrow-barred Spanish mackerel (Scomberomorus commerson) suggest a single genetic stock in the ROPME sea area (Arabian Gulf, Gulf of Oman, and Arabian Sea)," ICES Journal of Marine Science, vol. 63, no. 6, pp. 1066-1074, 2006.

[105] M. Ortiz, E. D. Prince, J. E. Serafy et al., "Global overview of the major constituent-based billfish tagging programs and their results since 1954," Marine and Freshwater Research, vol. 54, no. 4, pp. 489-507, 2003.

[106] S. A. Eckert, L. L. Dolar, G. L. Kooyman, W. Perrin, and R. A. Rahman, "Movements of whale sharks (Rhincodon typus) in South-east Asian waters as determined by satellite telemetry," Journal of Zoology, vol. 257, no. 1, pp. 111-115, 2002.

[107] E. B. Brothers and R. E. Thresher, "Pelagic duration, dispersal, and the distribution of Indo-Pacific coral reef fishes," in The Ecology of Coral Reefs, M. L. Reaka, Ed., pp. 53-70, NOAA, Washington, DC, USA, 1st edition, 1985.

[108] F. B. R. Lasram, J. A. Tomasini, F. Guilhaumon, M. S. Romdhane, T. Do Chi, and D. Mouillot, "Ecological correlates of dispersal success of Lessepsian fishes," Marine Ecology Progress Series, vol. 363, pp. 273-286, 2008.

[109] W. Dall, The Biology of the Penaeidae, Academic PrCalifornia, USA, 1st edition, 1990.

[110] B. A. Grantham, G. L. Eckert, and A. L. Shanks, "Dispersal potential of marine invertebrates in diverse habitats," Ecological Applications, vol. 13, no. 1, pp. 108-116, 2003.

[111] S. Katsanevakis and G. Verriopoulos, "Den ecology of Octopus vulgaris Cuvier, 1797, on soft sediment: availability and types of shelter," Scientia Marina, vol. 68, no. 1, pp. 147157, 2004.

[112] C. White and H. Costello, "Matching spatial property rights fisheries with scales of fish dispersal," Ecological Applications, vol. 21, no. 2, pp. 350-362, 2011.

[113] G. R. Russ, A. C. Alcala, and A. P. Maypa, "Spillover from marine reserves: the case of Naso vlamingii at Apo Island, the Philippines," Marine Ecology Progress Series, vol. 264, pp. 1520, 2003.

[114] A. Forcada, C. Valle, J. L. Sánchez-Lizaso, J. T. Bayle-Sempere, and F. Corsi, "Structure and spatio-temporal dynamics of artisanal fisheries around a Mediterranean marine protected area," Journal of Marine Science, vol. 67, no. 2, pp. 191-203, 2010.

[115] R. Hilborn, A. E. Punt, and J. Orensanz, "Beyond band-aids in fisheries management: fixing world fisheries," Bulletin of Marine Science, vol. 74, no. 3, pp. 493-507, 2004.

[116] W. J. F. Le Quesne, "Are flawed MPAs any good or just a new way of making old mistakes?" ICES Journal of Marine Science, vol. 66, no. 1, pp. 132-136, 2009.

[117] D. Pauly, "On the interrelationships between natural mortality, growth parameters, and mean environmental temperature in 175 fish stocks," Journal du Conseil, vol. 39, no. 2, pp. 175-192, 1980

[118] D. Pauly, "A simple method for estimating the food consumption of fish populations from growth data and food conversion experiments," Fishery Bulletin, vol. 84, no. 4, pp. 827-840, 1986.

[119] G. M. Jolly and I. Hampton, "A stratified random transect design for acoustic surveys of fish stocks," Canadian Journal of Fisheries and Aquatic Sciences, vol. 47, pp. 1282-1291, 1990.

[120] P. J. Mous and A. H. Muljadi, "Monitoring kesehatan karang di sekitar Kofiau dan Boo, Raja Ampat," Indonesia monitoring protocol V3.0. The Nature Conservancy Coral Triangle Center. Jl Pengembak 2, Sanur, Bali, Indonesia, 2005.

[121] P. J. Mous, "Aerial survey of marine resource use from small fixed-wing aircraft," A protocol for field operations of The Nature Conservancy Coral Triangle Center. Jl. Pengembak 2, Sanur, Bali, Indonesia, 2005.

[122] M. Barmawi, "Aerial survey in Raja Ampat: an observation of fisheries activity, large marine fauna, and coastal habitat," Data Report number 2, The Nature Conservancy Coral Triangle Center. Jl., Denpasar, Indonesia, 2006. 

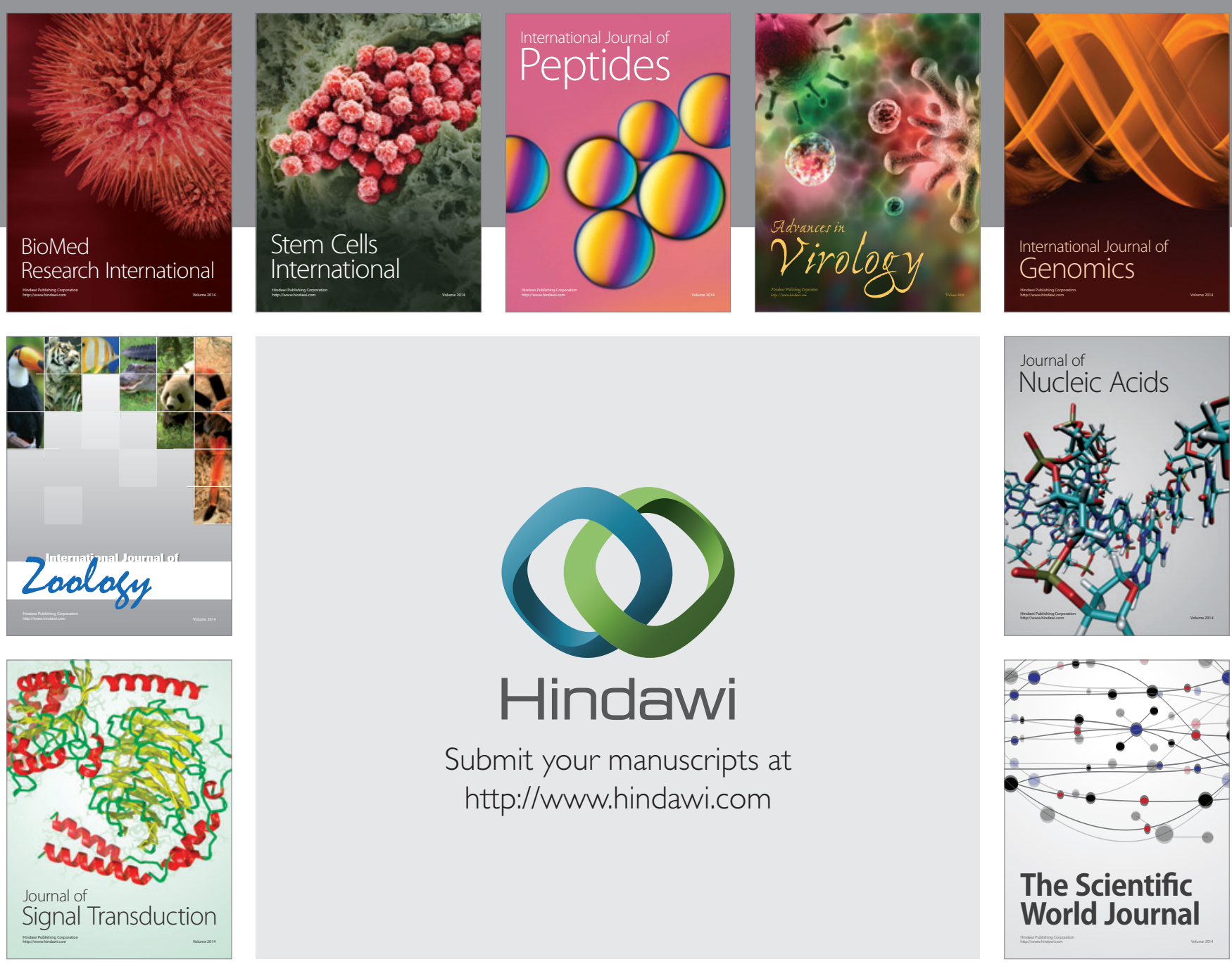

Submit your manuscripts at

http://www.hindawi.com
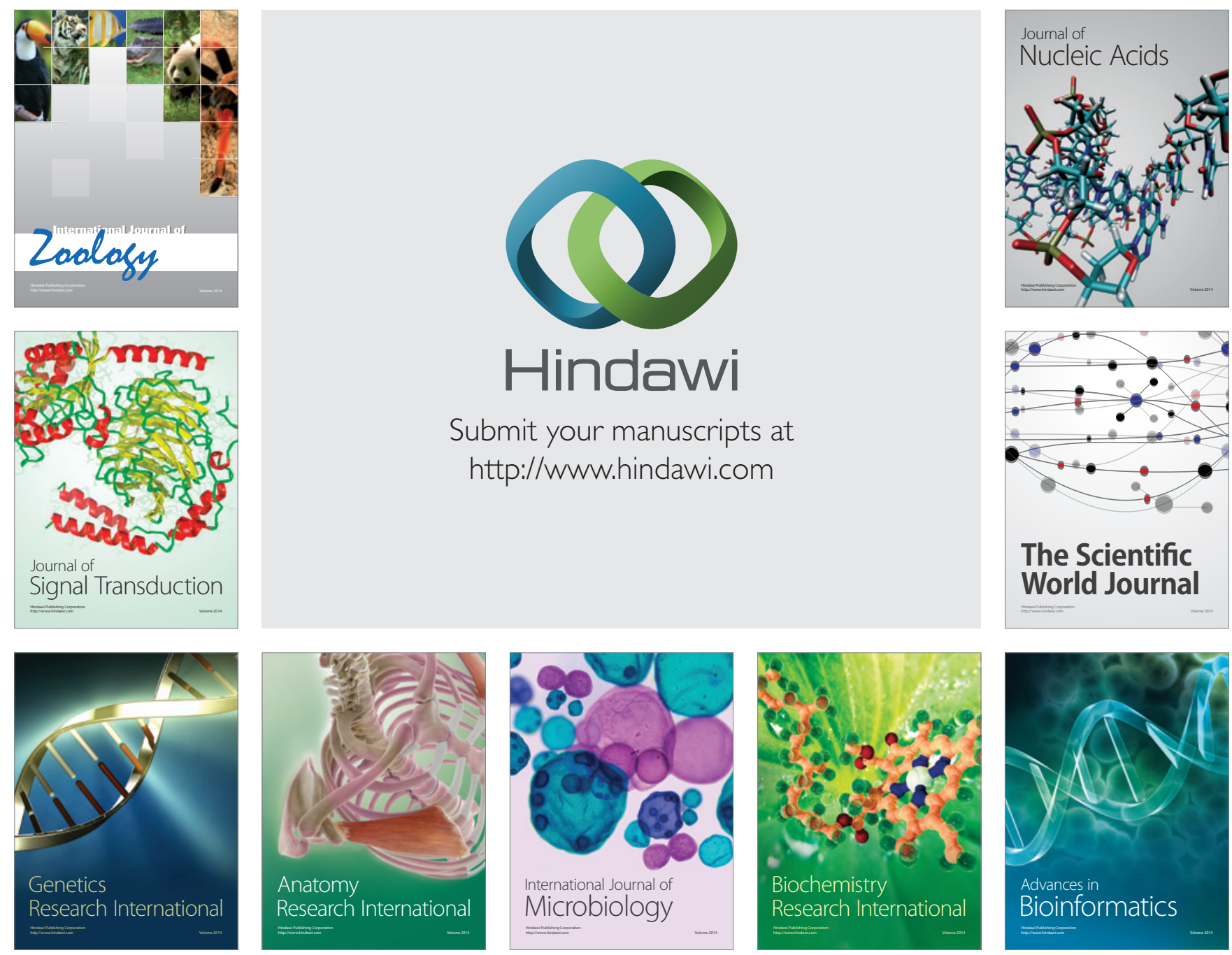

The Scientific World Journal
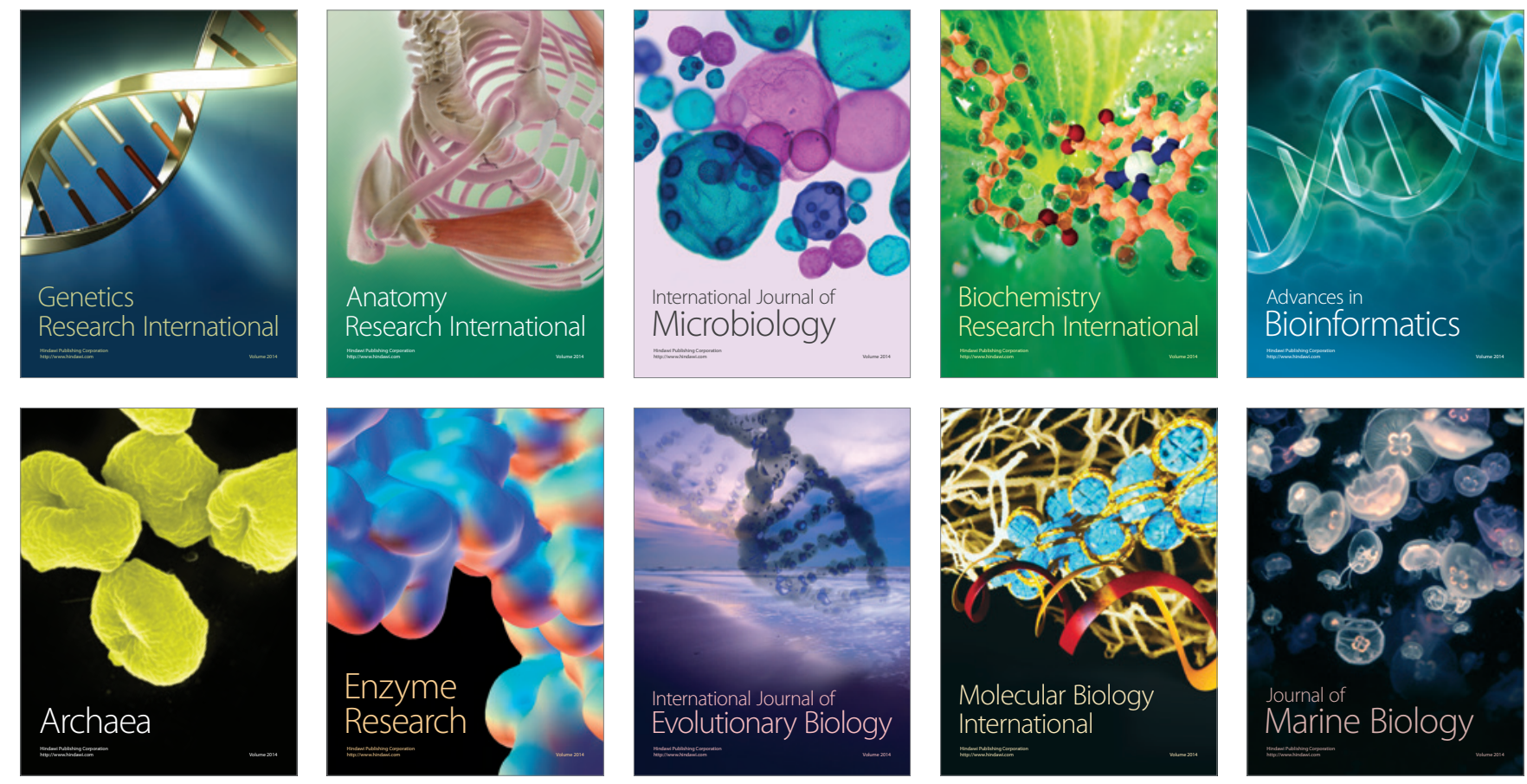